\title{
Developmental Expression of Transforming Growth Factor Induced Protein Promotes NF- Kappa-B Mediated Angiogenesis During Postnatal Lung Development
}

\author{
Min Liu $\mathrm{PhD}^{1}$, Cristiana Iosef $\mathrm{PhD}^{1}$, Shailaja Rao $\mathrm{PhD}^{1}$, Racquel Domingo-Gonzalez ${ }^{1}$, Sha Fu $\mathrm{MD}^{1,2}$, \\ Paige Snider $\mathrm{PhD}^{3}$, Simon J. Conway $\mathrm{PhD}^{3}$, Gray S. Umbach $\mathrm{MD}^{1,4}$, Sarah C. Heilshorn ${ }^{5}$, Ruby E. Dewi ${ }^{5}$, \\ Mar J. Dahl ${ }^{6}$, Donald M. Null MD ${ }^{6}$, Kurt H. Albertine $\mathrm{PhD}^{6}$, and Cristina M. Alvira MD ${ }^{1}$. \\ ${ }^{1}$ Stanford University, Department of Pediatrics, Center for Excellence in Pulmonary Biology, ${ }^{2}$ Liuyang People's \\ Hospital, Hunan, China, ${ }^{3} \mathrm{HB}$ Wells Center for Pediatric Research, Indiana University School of Medicine, \\ Indianapolis, IN 46202, USA, ${ }^{4}$ University of Texas Southwestern Medical School, ${ }^{5}$ Stanford University, Department \\ of Materials Science \& Engineering, ${ }^{6}$ Department of Pediatrics, University of Utah School of Medicine.
}

Address for Correspondence: $\quad$ Cristina M. Alvira, M.D.

Stanford University School of Medicine Center for Excellence in Pulmonary Biology

770 Welch Road, Suite 435

Palo Alto, CA 94304

Tel: 650-723-7297, FAX: 650-725-0171

Email: calvira@stanford.edu

Running Title: TGFBI Promotes Pulmonary Angiogenesis

Descriptor number: 3.3 Developmental Lung Biology or 14.3 Neonatal Lung Disease \& BPD

Word Count: 3495

Subject Codes: Angiogenesis, Developmental Biology. Pulmonary Biology

Contributions: ML, CI, SR, SF, GSU, RD, SCH, and CMA designed and executed studies, analyzed and interpreted results. PS and SJC created the TGFBI null mice. MJD, DMN, and KHA designed and executed the studies on preterm lambs. ML and CMA drafted the manuscript. All authors contributed edits and significant have given final approval for publication and agree to be accountable for the integrity of the information contained in this manuscript.

Support: This work was supported by National Institutes of Health grants HL122918 (CMA) HL148165 (SJC) HL 110002 (KHA), the Stanford Maternal Child Health Institute, Tashia and John Morgridge Faculty Scholar Award (CMA), The Stanford Chemical Engineering Undergraduate Summer Research Program (GSU), The Stanford CJ Huang SAMSUNG Fellowship (SF), and The University of Utah School of Medicine Division of Neonatology (KHA).

This article has an online data supplement, which is accessible from this issue's table of content online at www.atsjournals.org 


\begin{abstract}
:
Rationale: Pulmonary angiogenesis is a key driver of alveolarization. Our prior studies showed
\end{abstract} that nuclear factor kappa-B (NFאB) promotes pulmonary angiogenesis during early alveolarization. However, the mechanisms regulating temporal-specific NFKB activation in the pulmonary vasculature are unknown. Objectives: To identify mechanisms that activate proangiogenic NFאB signaling in the developing pulmonary vasculature. Methods: Proteomic analysis of the lung secretome was performed using 2D-DIGE. NFאB activation and angiogenic function was assessed in primary pulmonary endothelial cells (PEC) and TGFBI-regulated genes identified using RNA-sequencing. Alveolarization and pulmonary angiogenesis was assessed in WT and TGFBI null mice exposed to normoxia or hyperoxia. Lung TGFBI expression was determined in premature lambs supported by invasive and noninvasive respiratory support. Measurements and Main Results: Secreted factors from the early alveolar, but not the late alveolar or adult lung, promoted proliferation and migration in quiescent, adult PEC. Proteomic analysis identified transforming growth factor beta-induced protein (TGFBI) as a protein highly expressed by myofibroblasts in the early alveolar lung that promoted PEC migration by activating NF $\kappa \mathrm{B}$ via $\alpha v \beta 3$ integrins. RNA-sequencing identified $C s f 3$ as a TGFBI-regulated gene that enhances nitric oxide production in PEC. Loss of TGFBI in mice exaggerated the impaired pulmonary angiogenesis induced by chronic hyperoxia, and TGFBI expression was disrupted in premature lambs with impaired alveolarization. Conclusions: Our studies identify TGFBI as a developmentally-regulated protein that promotes $\mathrm{NF \kappa B}-$ mediated angiogenesis during early alveolarization by enhancing nitric oxide production. We speculate that dysregulation of TGFBI expression may contribute to diseases marked by impaired alveolar and vascular growth.

\title{
Abstract Word Count: 248
}


bioRxiv preprint doi: https://doi.org/10.1101/2020.05.28.121871; this version posted May 29, 2020. The copyright holder for this preprint (which

was not certified by peer review) is the author/funder, who has granted bioRxiv a license to display the preprint in perpetuity. It is made available under aCC-BY-NC-ND 4.0 International license.

Key Words: Alveolarization, endothelial migration, colony stimulating factor-3, nitric oxide production, bronchopulmonary dysplasia. 


\section{Introduction}

In contrast to many organs, significant lung development occurs postnatally. During alveolarization, the final stage of lung development, division of primitive airspaces by secondary septation, and exponential growth of the pulmonary microvasculature by angiogenesis markedly increases gas exchange surface area (1). As the lung matures, alveolarization and angiogenesis slows, and the pulmonary endothelium transitions from an activated to a quiescent phenotype characteristic of the mature vasculature (2).

Pulmonary angiogenesis is a key driver of alveolarization. Inhibiting angiogenesis impairs alveolarization, while enhancing angiogenesis preserves alveolarization during injury (3-5). Dysregulated angiogenesis is observed in premature infants with bronchopulmonary dysplasia (BPD), a chronic lung disease characterized by impaired alveolarization that represents the most common complication of extreme prematurity (6). The extension of alveolarization into postnatal life provides an important window of opportunity for lung repair and regeneration (7). Thus, elucidating pathways that promote pulmonary angiogenesis and alveolarization have important clinical implications.

We previously showed that endogenous NFKB activation promotes pulmonary angiogenesis in the early alveolar lung (8). Blocking NFאB in early alveolar pulmonary endothelial cells (PEC) impairs angiogenic function, and pharmacologic inhibition of NFKB in young mice impairs alveolar and vascular growth yet has no effect on adult mice. However, the mechanisms that induce temporal-specific activation of $\mathrm{NF} \kappa \mathrm{B}$ in the developing pulmonary vasculature remain unknown.

The tissue microenvironment modulates angiogenesis in development and disease. During early lung development, the alveolar epithelium regulates vascular patterning by expressing VEGF 
to promote EC survival, proliferation, and migration. In cancer, activated stromal fibroblasts develop a myofibroblast phenotype, co-localize with tumor vasculature, and promotes angiogenesis by expressing growth factors and modulating the extracellular matrix (9). Although myofibroblasts are required for alveolarization (10), whether they function to regulate pulmonary angiogenesis has not been explored.

In this study, we hypothesized that unique factors in the early alveolar microenvironment induce temporal-specific activation of $\mathrm{NF \kappa B}$ in the pulmonary endothelium. We profiled the lung secretome during development and identified transforming growth factor beta-induced protein (TGFBI) as protein highly expressed by myofibroblasts during early alveolarization. We show that TGFBI induces NFKB activation through $\alpha v \beta 3$ integrins, increasing nitric oxide (NO) production by increasing the expression of colony stimulating factor-3 (Csf3), an NFאB downstream target gene. TGFBI null mice exhibit decreased pulmonary vascular density, and a marked impairment of alveolar and vascular growth in repose to chronic hyperoxia. Further, TGFBI expression was dysregulated in a premature lamb model of disrupted alveolarization. Together, our data identify a novel myofibroblast-endothelial cell axis that serves to guide pulmonary angiogenesis during early alveolarization and implicate a role for dysregulated TGFBI in the pathogenesis of BPD.

Methods: Please see the Online Methods for full details.

\section{Animal Models}

C57BL/6 neonatal mice at early alveolarization (P6) and adult mice were purchased from Charles River Lab. TGFBI-/- mice have been described previously (11). Mice containing an endothelial cell specific deletion of IKK $\beta$ were generated by crossing IKK $\beta^{\mathrm{fl} / \mathrm{fl}}$ mice (12) with 
$P d g f b$-iCre mice (13). For hyperoxia experiments, litters of $\mathrm{P} 0$ pups were maintained in room air (normoxia) or $80 \% \mathrm{O}_{2}$ (hyperoxia) for 14 days (14). Lung morphometric analysis was performed as previously described $(8,15)$.

The methods for delivery and management of chronically ventilating preterm lambs are reported (16-19). Time-pregnant ewes at $132 \pm 2 \mathrm{~d}$ of gestation (term $\sim 150 \mathrm{~d}$ gestation) were used. At $\sim 3 \mathrm{~h}$ of age, the preterm lambs were randomized to IMV or NRS, as previously described (18) for a total of 21d. Control lambs were born at term.

Protocols for the animal studies adhered to American Physiological Society/US National Institutes of Health guidelines for humane use of animals for research and were prospectively approved by the Institutional Animal Care and Use Committee at Stanford University and the University of Utah Health Sciences Center.

\section{Lung Conditioned Media}

Lung conditional medium (LCM) was prepared from lung tissue from C5BL/6 mice at the early alveolar (P6), late alveolar (P16) and adult (8-10 weeks) stages of development (20), and proteins analyzed by 2D DIGE protein expression profiling.

\section{Western Immunoblot and Immunofluorescence}

Whole cell protein lysates were extracted from lung tissue and western blot performed (15). Immunostaining was performed on formalin-fixed or frozen lung sections (8), probed with primary antibodies against CD31, TGFBI, NFאB p65 or von Willebrand factor. 
PEC were isolated from P6 or adult C57BL/6, Tgfbi $i^{(-/)}$and $T g f b i^{(+/+),}$and Pdgfb-iCre ${ }^{(+/-)}$ $\operatorname{IKK} \beta^{\mathrm{fl} / \mathrm{fl}}$ mice as described previously $(8,15)$. Cells from passage $0-2$ were used for all assays as described in the Supplemental Methods. TGFBI neutralization was performed with anti-TGFBI antibodies (4 $\mu \mathrm{g} / \mathrm{ml})$, TGFBI stimulation with recombinant TGFBI $(10 \mu \mathrm{g} / \mathrm{ml})$, NFkB inhibition with the pharmacologic inhibitor, BAY11-0782 (2.5 $\mu \mathrm{M})$, and $\alpha v \beta 3$ inhibition with signaling anti$\alpha v \beta 3$ integrin $(4 \mu \mathrm{g} / \mathrm{ml})$ antibodies.

\section{RNA interference:}

PEC were transfected NTC, integrin $\alpha \mathrm{V}$, integrin $\beta 3$, or Csf3 On-Target Plus SMART pool siRNA using Lipofectamine 2000 for 6h as previously described (21).

\section{RNA-Seq Analysis}

Total RNA was extracted and RNA-sequencing performed by Quick Biology. Genes showing altered expression with $\mathrm{P}<0.05$ and more than 1.5 -fold change were considered differentially expressed.

\section{Measurement of NO in PEC.}

NO production was determined by loading the cells with 4-amino-5-methylamino-2',7'difluorofluorescein diacetate (DAF-FM) (22) prior to immunofluorescent imaging as previously described (23).

\section{Statistics}


Statistical differences between two groups were determined by Student's t-test, One- or Two-Way ANOVA as appropriate. A P value of $\leq 0.05$ was considered statistically significant.

\section{Results:}

Factors secreted by the early alveolar lung activate pro-angiogenic pathways in adult PEC.

To determine if factors present in the early alveolar microenvironment activate NFKB and modulate PEC angiogenic function, we collected lung condition medium (LCM) from mice at different stages of development and assessed NFאB activation and PEC migration. Under control conditions, NFKB subunits are constitutively expressed, but only translocate to the nucleus upon activation. At baseline, adult PEC demonstrated minimal active NFאB (Fig. 1A). However, incubation with early alveolar LCM increased NFאB activation by 2.65 -fold $(\mathrm{P}<0.001)$ (Fig. 1A and B). In contrast, incubation with late alveolar LCM increased NFאB activation only slightly $(\mathrm{P}<0.05)$, and adult LCM had no effect. Similarly, adult PEC migrated slowly when cultured in starvation media (Fig. 1C). The early alveolar LCM was as effective as 5\% FBS in inducing adult PEC migration, resulting in $43 \%$ scratch closure $(\mathrm{P}<0.0001)$. In contrast, the adult LCM induced migration only minimally $(\mathrm{P}<0.05)$. Taken together, these data suggested that factors present in the early alveolar lung microenvironment can induce NFkB activation and promote migration in adult PEC.

\section{TGFBI is highly expressed in the early alveolar lung but absent in the adult lung.}

To identify factors uniquely present in the early alveolar lung microenvironment, we compared all of the secreted proteins in the three LCM by two-dimensional difference gel 
electrophoresis (2-D DIGE) (Fig. E1), and identified 20 proteins that were highly expressed in the early alveolar lung secretome by mass spectrometry (Table E1). Of this group we selected transforming growth factor induced protein (TGFBI) for further investigation, a classically secreted protein that has recently been shown to be highly expressed by myofibroblasts by single cell RNA sequencing of the developing mouse lung (24). We confirmed higher expression of TGFBI in the early alveolar LCM ( $\mathrm{P}<0.001$, Fig.2 A), and in agreement with previous data (11), highest TGFBI protein in whole lung during early alveolarization, followed by an age-dependent decrease over time (Fig. 2B). Immunostaining of early alveolar lung tissue identified numerous cells with intense TGFBI expression (Fig. 2C), located at the tips of secondary septa, characteristic locations for alveolar myofibroblasts. In contrast, TGFBI immunoreactivity was completely absent in the adult lung. Similar findings were observed in the lungs of lambs (Fig. 2D), with high TGFBI expression in cells at the septal tips at 1 day of life, corresponding to early alveolarization, but reduced TGFBI expression by three weeks of age.

\section{TGFBI is necessary and sufficient for promoting early alveolar and adult PEC migration.}

We next determined whether TGFBI was required for the early alveolar LCM to enhance adult PEC migration. The addition of anti-TGFBI antibodies, but not isotype control IgG, significantly impaired the capacity of the early alveolar LCM to promote adult PEC migration (P<0.0001, Fig.3A), but had no effect on its proliferative effect (Fig. 3B). To determine whether TGFBI was sufficient to promote PEC migration, we employed recombinant TGFBI (rTGFBI) in microfluidic chemotaxis assays that permitted the creation of stable, linear gradients of chemotactic agents. Early alveolar PEC exposed to a gradient of starvation media migrated randomly, while those exposed to a gradient of VEGF demonstrated directed migration toward the 
source $(\mathrm{P}<0.0001)$ (Fig. 3C). Both the early alveolar LCM and rTGFBI induced similar directed migration. Moreover, rTGFBI promoted migration of both the early alveolar and adult PEC in endothelial scratch assays and Boyden chamber assays (Fig. E2).

\section{TGFBI-mediated PEC migration is NFאB-dependent.}

We next assessed whether the pro-migratory effect of TGFBI is NFkB-dependent. Similar to the migration results, early alveolar LCM containing control IgG increased NFкB activation by $80 \%(\mathrm{P}<0.001)$, but the addition of anti-TGFBI antibodies significantly blunted this effect $(\mathrm{P}<0.05)$ (Fig. 4A). rTGFBI significantly increased NFאB activity in early alveolar PEC (Fig. 4B,

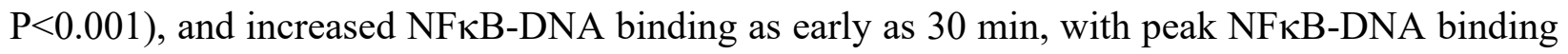
observed at $1 \mathrm{~h}$ (Fig. 4C). In addition, inhibiting NFאB with BAY-7082 (25), completely abrogated TGBFI-mediated migration $(\mathrm{P}<0.0001$, Fig. 4D). Further, we performed studies using PEC obtained from mice containing an endothelial-specific deletion of IKK $\beta$, the primary activator of NFאB in early alveolar PEC (21). Although rTGFBI increased migration in WT PEC $(\mathrm{P}<0.01)$, TGFBI-induced migration was absent in PEC lacking IKK $\beta$. Taken together, these data demonstrate that TGFBI-mediated migration is IKK $\beta / \mathrm{NF \kappa B}$ dependent (Fig. 4E).

\section{TGFBI-mediated NF אB activation and endothelial migration requires av $\beta 3$ integrins.}

We next performed studies to identify how TGFBI was mediating these effects. TGFBI contains a carboxy-terminal Arg-Gly-Asp (RGD) sequence that allows binding to integrins (26). We focused initially on $\alpha v \beta 3$, an integrin up-regulated in angiogenic vascular tissue (27), that

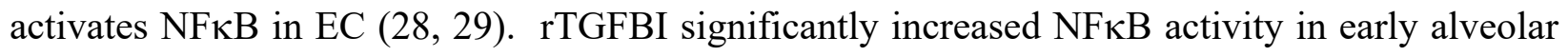
PEC pre-treated with control IgG but had no effect on on PEC treated with anti- $\alpha \mathrm{v} \beta 3$ integrin 
antibodies (Fig. 5A and B). Although both rTGFBI alone and rTGFBI+IgG promoted PEC migration to a similar degree (Fig. 5C), anti- $\alpha \mathrm{v} \beta 3$ antibodies completely blocked rTGFBI-induced PEC migration. Finally, we transfected early alveolar PEC with NTC, $\alpha$ v integrin, or $\beta 3$ integrin siRNA. In vehicle-stimulated cells, migration was similar between the three groups (Fig. 5D). rTGFBI significantly increased migration in the NTC-transfected PEC $(\mathrm{P}<0.01)$ but did not increase migration in PEC transfected with either $\alpha \mathrm{v}$ or $\beta 3$ siRNA.

\section{TGFBI increases Csf3, a modulator of NO, in early alveolar PEC.}

To identify mechanism by which TGFBI promotes PEC migration, we profiled TGFBIresponsive genes using RNA-Seq. Given that rTGFBI stimulated both early alveolar and adult PEC migration (Fig. E2), we looked for genes induced by rTGFBI in both groups. Hierarchical clustering of differentially expressed genes demonstrated good clustering of vehicle- and rTGFBIstimulated samples (Fig. 6A). rTGFBI significantly dysregulated 56 genes in early alveolar (Table E2) and 64 genes in adult PEC (Table E3), however, only 3 genes were shared (Fig. 6B). Colony stimulating factor-3 (Csf3), a known NFkB- target gene (30), was among the shared genes, upregulated 3.01-fold in early alveolar and 2.77-fold in adult PEC by rTGFBI (Fig. 6C). We confirmed that rTGFBI induced a 3.4-fold increase in Csf3 gene expression in early alveolar PEC by qPCR (Fig. 6D), and increased CSF3 protein (Fig. 6E). Prior studies found that CSF3 promotes EC migration by increasing in NO (31). Therefore, we loaded cells with the NO sensitive dye, DAF-FM diacetate prior to stimulation with vehicle or rTGFBI and found that rTGFBI increased NO in the PEC by more than 2-fold compared to vehicle (Fig. 6F). 


\section{Silencing Csf3 abrogates the TGFBI-mediated induction of NO and migration of early alveolar} $P E C$.

To determine if the TGFBI-mediated effects require $C s f 3$, we performed additional studies where we silenced $C s f 3$. Transfection of early alveolar PEC with $C s f 3$ siRNA effectively reduced CSF3 protein expression by 42h (Fig. 7A). rTGFBI increased migration 2-fold in NTC siRNAtransfected cells (Fig. 7B) but did not significantly enhance migration in Csf3 siRNA-transfected cells. rTGFBI also enhanced NO production in NTC siRNA-transfected cells (Fig. 7C). However, rTGFBI-mediated increases in NO were completely blocked with $C s f 3$ silencing. Taken together, these results demonstrate that TGFBI promotes PEC migration by augmenting Csf3-dependent NO production.

\section{Loss of TGFBI impairs pulmonary vascular growth in mice, and TGFBI expression is} dysregulated in preterm lambs with impaired alveolarization.

To assess the physiological role of TGFBI in alveolarization and pulmonary angiogenesis, we evaluated mice containing a global deletion of TGFBI in normoxia and in response to chronic hyperoxia, a stimulus that disrupts pulmonary angiogenesis and alveolarization (32). These mice were reported to have impaired alveolarization at baseline, but abnormalities in vascular growth were not observed. In keeping with prior results, TGFBI null mice $\left(\mathrm{TGFBI}^{-/}\right)$exhibited a $20 \%$ decrease in radial alveolar count $(\mathrm{P}<0.0001)$ and a $128 \%$ increase in distal airspace area $(\mathrm{P}<0.0001)$ compared to WT mice (Fig. 8A-C). As expected, chronic hyperoxia disrupted alveolarization in the WT mice, but induced a more exaggerated phenotype in the $\mathrm{TGFBI}^{-/-}$mice, reducing radial alveolar count by almost $70 \%(\mathrm{P}<0.0001)$ and further increased the already dilated distal airspaces $(\mathrm{P}<0.001)$. Under control conditions, TGFBI null mice exhibited a 33\% reduction 
in pulmonary vascular density as compared to WT $(\mathrm{P}<0.0001)$ (Fig. $8 \mathrm{D}$ and E). Chronic hyperoxia reduced pulmonary vascular density in WT mice by $46 \%(\mathrm{P}<0.0001)$, but caused a more exaggerated disruption of pulmonary vascular growth in $\mathrm{TGFBI}^{-/-}$mice, decreasing pulmonary vascular density by $70 \%(\mathrm{P}<0.0001)$, resulting in an almost 3 -fold reduction in distal vessels in $\mathrm{TGFBI}^{-/-}$compared to WT mice. Taken together, these results demonstrate that TGFBI is required for physiologic pulmonary vascular growth, and that loss of TGFBI worsens the detrimental effects of chronic hyperoxia on alveolarization and angiogenesis.

Finally, we explored whether TGFBI expression was altered in a large animal model of BPD, where preterm lambs are supported with either non-invasive respiratory support (NRS) or invasive mechanical ventilation (IMV). Control, term lambs had focal staining of TGFBI throughout the lung, including high expression at the tips of all the secondary septa (Fig. 8F, arrows). Preterm lambs supported with NRS exhibited many, thin secondary septa, and a marked reduction in TGFBI immunostaining. Preterm lambs supported by IMV, however, had abnormally thickened secondary septa, with a heightened expression but abnormal localization of TGFBI along the length of the thick secondary septa rather than the normal localization at the septal tips.

\section{Discussion:}

During early postnatal life, growth of the pulmonary vasculature serves as a driver of alveolarization. In this study, we explored the mechanisms that activate pro-angiogenic NFкB signaling in the pulmonary endothelium during early alveolarization. We identified TGFBI, as a secreted protein highly expressed in early alveolarization, corresponding to the time when NFkB 
is endogenously active in the pulmonary vasculature (8). We show that TGFBI activates NFкB in PEC and enhances NFкB-mediated EC migration via $\alpha v \beta 3$ integrins. We further show that TGFBI stimulation increases $\operatorname{Csf} 3$ expression, serving to enhance NO production. Finally, we demonstrate that loss of TGFBI in mice impairs pulmonary vascular development at baseline and severely impairs alveolar and vascular growth in chronic hyperoxia, and that TGFBI expression and localization is aberrant in a preterm lamb model of disrupted alveolarization. In summary, our studies identify a novel axis, whereby developmental expression of TGFBI activates NFאB and promotes pulmonary endothelial angiogenesis during this critical window of vascular development.

Pulmonary angiogenesis is essential for alveolarization, and disrupted angiogenesis contributes to the pathogenesis of bronchopulmonary dysplasia (BPD), the most common complication of premature birth (33). Our lab previously identified the NFאB pathway as an important regulator of pulmonary angiogenesis during alveolarization (8). However, the mechanisms allowing for temporal-specific activation of pro-angiogenic NFKB signaling in the pulmonary vasculature was not known. These results highlight the role of paracrine factors secreted from alveolar myofibroblasts in the creation of a pro-angiogenic niche that activates NFкB to support pulmonary vascular growth during early alveolarization.

By profiling developmental differences in the lung microenvironment, we identified TGFBI as a temporally-regulated protein highly expressed during early alveolarization. TGFBI binds both extracellular matrix $(34,35)$ and integrins (36-39), suggesting a possible role as a bifunctional linker protein that connects cells to the matrix (34). TGFBI mRNA is biphasically altered in the hyperoxia mouse model of BPD (11) and induced during bleomycin-mediated fibrotic lung injury (40). Importantly, single cell RNA sequencing in the developing murine lung 
identified TGFBI as a highly discriminating gene for myofibroblasts (24). In our study, TGFBI was expressed at the tips of secondary crests, characteristic locations for myofibroblasts (10), concordant with a prior report that identified high expression of TGFBI in the septal tips of a two year-old child, leading the authors to speculate a putative role in alveolar morphogenesis (41).

In other systems, TGFBI is regulated by TGF $\beta$. TGF $\beta$ isoforms play a complex role in lung development. Although TGF $\beta 1$ is required for lung branching and epithelial differentiation (42), exogenous TGF $\beta 1$ inhibits branching of pseudoglandular lung explants (-43). Loss of TGF $\beta 1$ does not disrupt lung development (44), but loss of TGF $\beta 3$ induces alveolar hypoplasia and extensive intrapulmonary hemorrhage, suggesting role for TGF $\beta 3$ in pulmonary vasculature stabilization (45). Impaired alveolarization is also observed in mice with global deletions of Smad3, the downstream effector of TGF $\beta$ (46). Taken together these data highlight the importance of precise TGF $\beta$ signaling in the correct cells at the right time to support lung development. Further studies will be needed to determine if TGF $\beta$ is the primary regulator of TGFBI in the early alveolar lung, however, as a putative downstream effector of TGF $\beta$, our data highlight a role for TGFBI in coordinating alveolar and vascular growth during alveolarization.

TGFBI promotes cell adhesion, migration and proliferation of diverse cell types by interacting via integrins $(37,47,48)$. We specifically investigated $\alpha v \beta 3$ integrins given their established role in angiogenesis. The $\alpha v \beta 3$ integrin is highly expressed by newly forming blood vessels(27). Activation of $\alpha v \beta 3$ promotes endothelial migration(49), and blocking $\alpha v \beta 3$ inhibits tumor angiogenesis (-50) and impairs lumen formation and vascular patterning in the embryo(51). Further, $\alpha v \beta 3$ activates $\mathrm{NF \kappa B}$ to promote $\mathrm{EC}$ adhesion, survival, and migration(28, 52). Moreover, TGFBI promotes adhesion and migration of human umbilical EC via $\alpha v \beta 3$ (39). Concordant with these studies, we found that TGFBI-stimulated PEC migration was blocked by 
inhibiting either NFkB or $\alpha v \beta 3$. Taken together, our data demonstrate that TGFBI promotes PEC migration via $\alpha v \beta 3$ to induce pro-angiogenic $\mathrm{NF \kappa B}$ signaling.

We next investigated the downstream mechanisms by which TGFBI promotes PEC migration, using RNA-Seq to identify novel TGFBI-regulated genes. One of the few, shared targets in early alveolar and adult PEC was Csf3 (encoding GCSF), a known NFkB-regulated target gene (30). A well-recognized hematopoetic growth factor (53), GCSF also promotes endothelial migration (54). GCSF is produced by EC stimulated with interleukin-1 (55), an NFкB activator (56), and increases the expression and activation of endothelial nitric oxide synthase (eNOS) to augment NO production $(31,57)$. NO is produced locally at lamellipodia of migrating human EC, and lung EC from eNOS null mice migrate more slowly and display impaired capillary formation (58-60). In our study, TGFBI increased NO production in PEC, and silencing Csf3 blocked both TGFBI-mediated NO production and PEC migration. In preterm lambs, prolonged IMV reduced eNOS protein and pulmonary capillary and microvessel abundance (61-63). Taken together, these studies identify $\operatorname{Cs} f 3$ as a central downstream mechanism for the pro-angiogenic effects of TGFBI.

Finally, as proof of concept for the importance of TGFBI in vivo, we performed studies using TGFBI-/- mice, and a preterm lamb model of impaired alveolarization $(11,18)$. We showed that TGFBI-/- mice have reduced pulmonary vascular density at baseline, and that chronic hyperoxia markedly exaggerated this vascular phenotype. Further, we found that TGFBI expression was reduced in preterm lambs treated with NRS, consistent with delayed alveolarization observed in this group. Importantly, in preterm lambs maintained with the more injurious, IMV strategy, TGFBI expression was abnormally increased along the thickened septal tips, similar to the abnormal accumulation of elastin and mesenchymal cell proliferation reported 
$(16,64)$. These studies suggest that both the correct amount and the correct location of TGFBI is required to optimally support vascular growth. Further, these preclinical studies support recent clinical studies that offer additional evidence of the importance of TGFBI in the developing human lung. In a study of 50 twin pairs affected and unaffected with BPD, rare variants in $T G F B I$ were associated with an increased risk for BPD (65). In a subsequent, larger study that employed whole exome sequencing in infants with extreme phenotypes of BPD, rare variants in $T G F B I$ were again identified in affected but not unaffected subjects (66). Taken together, these studies provide compelling data to highlight the importance of TGFBI in promoting distal lung development and implicate a role for disrupted TGFBI signaling in the pathogenesis of BPD.

In summary, our data identify a paracrine mechanism by which myofibroblast expression of TGFBI promotes pulmonary angiogenesis through an $\alpha v \beta 3 / \mathrm{NF} \kappa \mathrm{B}$ axis that increases CSF3mediated NO production. Given the ability of TGFBI to bind extracellular matrix components highly expressed in the developing lung, local secretion of TGFBI by myofibroblasts may serve to create an angiogenic niche that promotes pulmonary vascular growth along the developing septa. Taken together, our studies identify a novel pathway allowing for myofibroblast-endothelial cross talk, and we speculate that TGFBI dysregulation may contribute to the aberrant pulmonary angiogenesis observe in the setting of impaired alveolarization. 
bioRxiv preprint doi: https://doi.org/10.1101/2020.05.28.121871; this version posted May 29, 2020. The copyright holder for this preprint (which

was not certified by peer review) is the author/funder, who has granted bioRxiv a license to display the preprint in perpetuity. It is made available under aCC-BY-NC-ND 4.0 International license.

\section{Acknowledgements: None.}




\section{Figure Legends:}

Figure 1: Factors secreted by the early alveolar lung activate pro-angiogenic pathways in adult pulmonary endothelial cells. (A) Representative immunofluorescent images of adult PEC incubated with starvation media, or early alveolar (EA), late alveolar (LA) or adult lung conditioned media (LCM) for $24 \mathrm{~h}$ followed by immunostaining to detect the NFкB subunit, p65 (red) and chromatin (blue). (B) Quantification of the total intensity of nuclear p65 with $* \mathrm{P}<0.05$,

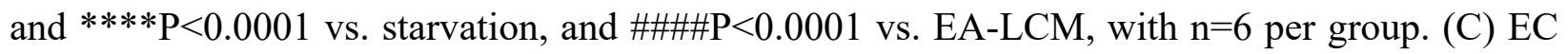
scratch assays performed using adult PEC incubated with starvation media, 5\% FBS, EA-LCM, and adult LCM, and the percent scratch area covered at $24 \mathrm{~h}$ calculated. $* * * * \mathrm{P}<0.0001$ vs. starvation, and \#\#\#\#P<0.0001 vs. EA-LCM, with n=3 per group.

Figure 2: TGFBI is highly expressed in the early alveolar lung but absent in the adult lung. (A) Western blot to determine TGFBI protein in the EA-, LA-, and adult LCM. $* * * * \mathrm{P}<0.0001$ vs. $\mathrm{EA}=\mathrm{LCM}$, with $\mathrm{n}=3$. (B) Western blot to determine TGFBI protein relative to $\beta$-actin in whole lung from mice at the early alveolar (P6), late alveolar (P16), and adult (P30) stages of development. $* * \mathrm{P}<0.01$ and $* * * * \mathrm{P}<0.0001$ vs. $\mathrm{P} 6$, and $\# \mathrm{P}<0.05$ vs. $\mathrm{P} 16$, with $\mathrm{n}=4$ per group. (C) Representative images obtained from lung cryosections obtained from P6 and adult mice to detect CD31 (green), TGFBI (red) and chromatin (blue). Arrows point to TGFBI-positive cells at tips of secondary septa. Calibration mark $=100 \mu \mathrm{m}$. (D) Representative images obtained from lung tissue from lambs at the early alveolar (Day 1) and late alveolar (3 week) stages of development to detect $\alpha$-smooth muscle-actin (green), TGFBI (red) and chromatin (blue). Calibration mark $=50 \mu \mathrm{m}$. 
Figure 3: TGFBI is necessary and sufficient to promote PEC migration. (A) Endothelial scratch assays were performed using adult PEC incubated with starvation media, 5\% FBS, EALCM, EA-LCM plus isotype control IgG, and EA-LCM plus anti-TGFBI antibodies (4 $\mu \mathrm{g} / \mathrm{ml})$ and the percent scratch area covered at $24 \mathrm{~h}$ calculated. $* * * * \mathrm{P}<0.0001$ vs. starvation, and \#\#\#P<0.0001 vs. EA-LCM, with $\mathrm{n}=3$ per group. Representative results from three separate experiments. (B) BrdU incorporation assays to assess adult PEC proliferation at $24 \mathrm{~h}$ in cells incubated with 5\% FBS, EA-LCM, EA-LCM + IgG, and EA-LCM + anti-TGFBI antibodies. $* * * * \mathrm{P}<0.0001$ vs. starvation with $\mathrm{n}=3-6$ per group. (C) Tracks of individual cells (top) and directional histograms (bottom) from live cell imaging and tracking of early alveolar PEC subjected to microfluidic chemotaxis assays performed with starvation media, EA-LCM, starvation +TGFBI or starvation + VEGF $(50 \mathrm{ng} / \mathrm{ml})$ with each chamber containing a source on the right side and a sink on the left. Total number of individual cells tracked is reported in the upper left corner, and the number of cells migrating away (black) or toward (red) in the bottom left and right corners respectively. In each group there were between 3-5 cells with a migration of net zero, accounting for the remaining cells making up the total $\mathrm{n}$ number. $\mathrm{P}$ value is shown on the image.

Figure 4: TGFBI-mediated pulmonary endothelial cell migration is NFкB-dependent. (A) Representative images of adult PEC incubated with starvation media, EA-LCM + IgG, and EALCM + anti-TGFBI antibodies for $24 \mathrm{~h}$ followed by immunostaining to detect p65 (red) and chromatin (blue), with quantification to determine the total intensity of nuclear p65 over nuclear area. ${ }^{*} \mathrm{P}<0.05$, and $* * * \mathrm{P}<0.001$ vs. starvation, and $\# \mathrm{P}<0.05$ vs. EA-LCM + IgG, with $\mathrm{n}=5$ per group. (B) Representative images from early alveolar PEC incubated with starvation media + 
vehicle or starvation media + rTGFBI for $24 \mathrm{~h}$ stained to detect the p65 (red), CD31(green), and DAPI (blue), with quantification of total intensity of nuclear p65. **** $\mathrm{P}<0.0001$ with $\mathrm{n}=127$ control cells and $n=112$ rTGFBI-stimulated cells. (C) Representative EMSA to detect NFאB-DNA binding in early alveolar PEC exposed to starvation media, or starvation media + TGFBI. (D) Scratch assays using early alveolar PEC stimulated with starvation media, starvation media + rTGFBI, or starvation media +rTGFBI and BAY 11-7082 $(2.5 \mu \mathrm{M})$, with the percent scratch area covered at $24 \mathrm{~h}$ calculated. $* * * \mathrm{P}<0.001$ vs. starvation and \#\#\#\#P<0.0001 vs. rTGFBI, with $\mathrm{n}=4$ per group. (E) Scratch assays performed using wild type PEC $\left(\mathrm{IKK} \beta^{+/+}\right)$and PEC lacking the NFKB activator, IKK $\beta\left(\mathrm{IKK}^{-/-}\right)$stimulated with starvation media, EGM, starvation media + rTGFBI and the percent scratch area covered at $24 \mathrm{~h}$ calculated. $* * \mathrm{P}<0.01$ and $* * * * \mathrm{P}<0.0001$ vs. starvation and $\# \mathrm{P}=0.003$ vs. TGFBI IKK $\beta^{+/+}$, with $\mathrm{n}=4$ per group.

Figure 5: TGFBI-mediated endothelial migration requires $\alpha v \beta 3$ integrins. (A) Representative images obtained from early alveolar PEC pretreated with either IgG or anti- $\alpha \mathrm{v} \beta 3$ antibodies prior to stimulation with starvation media + vehicle or starvation media + rTGFBI for $24 \mathrm{~h}$ stained to detect the p65 (red), CD31(green), and DAPI (blue), with (B) quantification of total intensity of nuclear $\mathrm{p} 65 . * * \mathrm{P}<0.01$ versus starvation $+\mathrm{IgG}$, and \#\# versus $\mathrm{rTGFBI}+\mathrm{IgG}$ with $\mathrm{n}=4$. (C) Scratch assays with early alveolar PEC incubated with starvation media, EGM, starvation media + rTGFBI, starvation media + rTGFBI + IgG, and starvation media + rTGFBI plus anti- $\alpha v \beta 3$ antibodies and the percent scratch area covered at $24 \mathrm{~h}$ calculated. $* \mathrm{P}<0.05$ and $* * * \mathrm{P}<0.001$ vs. starvation and $\# \# \mathrm{P}<0.01$ vs. starvation $+\mathrm{rTGFBI}+\mathrm{IgG}$, with $\mathrm{n}=3$ per group. Representative result from 2 independent experiments. (D) Scratch assays were performed using early alveolar PEC transfected with NTC, integrin $\alpha \mathrm{v}$, and integrin $\beta 3$ siRNA. At $48 \mathrm{~h}$ post transfection, the groups 
were incubated with starvation media, EGM, starvation media + rTGFBI and the percent scratch area covered at $24 \mathrm{~h}$ calculated. $* * \mathrm{P}<0.01$ vs. starvation, and $\# \mathrm{P}<0.05$ and $\# \# \mathrm{P}<0.01$ vs. NTC stimulated with rTGFBI, with $n=3-4$ per group. Representative result from 4 independent experiments.

Figure 6: TGFBI increases the expression of Csf3, a modulator of nitric oxide, in early alveolar PEC. (A) Heat map of differentially expressed genes identified by RNA-Seq in early alveolar and adult PEC stimulated with vehicle or rTGFBI for 6h. Up-regulated genes are in red and down-regulated genes in green. (B) Venn diagram of unique and shared TGFBI-regulated genes in early alveolar and adult PEC. (C) Csf3 was a gene up-regulated by rTGFBI in both early alveolar and adult PEC. (D) Gene expression of $C s f 3$ was determined by qRT-PCR in early alveolar PEC stimulated with vehicle or $\mathrm{rTGFBI}$ for $6 \mathrm{~h}$. ${ }^{*} \mathrm{P}<0.05$ vs. vehicle with $\mathrm{n}=4$ per group. (E) Representative western blot to detect CSF3 protein expression in whole cell lysates obtained from early alveolar PEC stimulated with vehicle or rTGFBI for 4hr. (F) NO production assays in early alveolar PEC stimulated with starvation media containing vehicle or rTGFBI for 4hr and 24h, and loaded with the NO sensitive dye, DAF-FM. Representative images taken to detect NO (green) and chromatin (blue). Calibration mark $=100 \mu \mathrm{m}$. Quantification of the raw integrated density of NO fluorescent signal per cell in early alveolar PEC stimulated with vehicle or rTGFBI for $4 \mathrm{~h}$ and $24 \mathrm{hr}$, respectively, with $* * \mathrm{P}<0.01$, and $* * * \mathrm{P}<0.0001$ vs. vehicle, with $\mathrm{n}=5-8$ per group. Results are representative of 3 independent experiments.

Figure 7: Silencing Csf3 abrogates the TGFBI-mediated induction of NO and migration of early alveolar PEC. (A) Representative western blot to detect Csf3 protein expression relative to 
$\beta$-actin in early alveolar PEC transfected with NTC and Csf3 siRNA. (B) Boyden chamber assays to detect chemotactic migration in early alveolar PEC transfected with NTC or Csf3 siRNA incubated at $48 \mathrm{~h}$ after transfection with starvation media or starvation media containing rTGFBI for $8 \mathrm{~h} . * * * * \mathrm{P}<0.0001$ vs. vehicle NTC siRNA and \#\#P<0.01 vs. NTC siRNA TGFBI, with n=1012 replicates. Results are a representative example of three independent experiments. (C) NO production assays in early alveolar PEC transfected with NTC or Csf3 siRNA and stimulated with starvation + rTGFBI for 24h. Representative images to detect NO (green) and chromatin (blue). Quantification of the raw integrated density of NO fluorescence per cell in early alveolar PEC stimulated with vehicle or rTGFBI for $24 \mathrm{~h}$. $* * * * \mathrm{P}<0.0001$ vs. vehicle, and $\#^{\# \# \#} \mathrm{P}<0.0001$ vs. rTGFBI stimulated NTC transfected.

Figure 8. Loss of TGFBI in mice impairs pulmonary parenchymal and vascular growth and TGFBI expression is dysregulated in experimental models of impaired alveolarization. (A) Representative images obtained from P14 wild type (WT) and $\mathrm{TGFBI}^{-/-}$mice maintained in normoxia or chronic hyperoxia $\left(80 \% \mathrm{O}_{2}\right.$ from P1-P14). Calibration bar=100 $\mu \mathrm{m}$. Quantification of radial alveolar counts $(\mathrm{B})$ and $(\mathrm{C})$ distal airspace area. $* * \mathrm{P}<0.01$ and $* * * * \mathrm{P}<0.0001$ vs. normoxia, and $\# \# \# \mathrm{P}<0.001$ and $\# \# \# \# \mathrm{P}<0.0001$ vs. WT via $2-\mathrm{WAY}$ ANOVA, with $\mathrm{n}=4-7$ per group. (D) Representative images stained to detect vWF (red) and DAPI (blue). Calibration bar $=100 \mu \mathrm{m}$. (E) Quantification of vWF-stained vessels less than $100 \mu \mathrm{m}$ per high powered field in 20 nonoverlapping sections per mouse. $* * * * \mathrm{P}>0.0001$ vs. normoxia, and \#\#\#\#P<0.0001 vs. WT with $\mathrm{n}=5-7$ mice per group. (F) Representative images obtained from control term newborn lambs, and premature lambs treated with noninvasive respiratory support (NRS) or invasive mechanical 
bioRxiv preprint doi: https://doi.org/10.1101/2020.05.28.121871; this version posted May 29, 2020. The copyright holder for this preprint (which

was not certified by peer review) is the author/funder, who has granted bioRxiv a license to display the preprint in perpetuity. It is made available under aCC-BY-NC-ND 4.0 International license.

ventilation (IMV), stained to detect TGFBI (red), alpha-smooth muscle actin (green) and chromatin (blue). Calibration bar $=20 \mu \mathrm{m}$. 


\section{References:}

1. Bourbon J, Boucherat O, Chailley-Heu B, and Delacourt C. Control mechanisms of lung alveolar development and their disorders in bronchopulmonary dysplasia. Pediatr Res. 2005;57(5 Pt 2):38R-46R.

2. Schlereth K, Weichenhan D, Bauer T, Heumann T, Giannakouri E, Lipka D, et al. The transcriptomic and epigenetic map of vascular quiescence in the continuous lung endothelium. Elife. 2018;7: e34423

3. Jakkula M, Le Cras TD, Gebb S, Hirth KP, Tuder RM, Voelkel NF, et al. Inhibition of angiogenesis decreases alveolarization in the developing rat lung. Am J Physiol Lung Cell Mol Physiol. 2000;279(3):L600-7.

4. Le Cras TD, Markham NE, Tuder RM, Voelkel NF, and Abman SH. Treatment of newborn rats with a VEGF receptor inhibitor causes pulmonary hypertension and abnormal lung structure. Am J Physiol Lung Cell Mol Physiol. 2002;283(3):L555-62.

5. Thébaud B, Ladha F, Michelakis ED, Sawicka M, Thurston G, Eaton F, et al. Vascular endothelial growth factor gene therapy increases survival, promotes lung angiogenesis, and prevents alveolar damage in hyperoxia-induced lung injury: evidence that angiogenesis participates in alveolarization. Circulation. 2005;112(16):2477-86.

6. Islam JY, Keller RL, Aschner JL, Hartert TV, and Moore PE. Understanding the Shortand Long-Term Respiratory Outcomes of Prematurity and Bronchopulmonary Dysplasia. Am J Respir Crit Care Med. 2015;192(2):134-56.

7. Baker CD, and Alvira CM. Disrupted lung development and bronchopulmonary dysplasia: opportunities for lung repair and regeneration. Curr Opin Pediatr. 2014;26(3):306-14. 
8. Iosef C, Alastalo TP, Hou Y, Chen C, Adams ES, Lyu SC, et al. Inhibiting NF-kappaB in the developing lung disrupts angiogenesis and alveolarization. Am J Physiol Lung Cell Mol Physiol. 2012;302(10):L1023-36.

9. De Palma M, Biziato D, and Petrova TV. Microenvironmental regulation of tumour angiogenesis. Nat Rev Cancer. 2017;17(8):457-74.

10. Bostrom H, Willetts K, Pekny M, Leveen P, Lindahl P, Hedstrand H, et al. PDGF-A signaling is a critical event in lung alveolar myofibroblast development and alveogenesis. Cell. 1996;85(6):863-73.

11. Ahlfeld SK, Wang J, Gao Y, Snider P, and Conway SJ. Initial Suppression of Transforming Growth Factor-beta Signaling and Loss of TGFBI Causes Early Alveolar Structural Defects Resulting in Bronchopulmonary Dysplasia. Am J Pathol. 2016;186(4):777-93.

12. Li ZW, Omori SA, Labuda T, Karin M, and Rickert RC. IKK beta is required for peripheral B cell survival and proliferation. J Immunol. 2003;170(9):4630-7.

13. Claxton S, Kostourou V, Jadeja S, Chambon P, Hodivala-Dilke K, and Fruttiger M. Efficient, inducible Cre-recombinase activation in vascular endothelium. Genesis. 2008;46(2):74-80.

14. Hilgendorff A, Reiss I, Ehrhardt H, Eickelberg O, and Alvira CM. Chronic lung disease in the preterm infant. Lessons learned from animal models. Am J Respir Cell Mol Biol. $2014 ; 50(2): 233-45$.

15. Hou Y, Liu M, Husted C, Chen C, Thiagarajan K, Johns JL, et al. Activation of the nuclear factor-kappaB pathway during postnatal lung inflammation preserves alveolarization by suppressing macrophage inflammatory protein-2. Am J Physiol Lung Cell Mol Physiol. 2015;309(6):L593-604. 
16. Reyburn B, Li M, Metcalfe DB, Kroll NJ, Alvord J, Wint A, et al. Nasal ventilation alters mesenchymal cell turnover and improves alveolarization in preterm lambs. Am J Respir Crit Care Med. 2008;178(4):407-18.

17. Albertine KH, Dahl MJ, Gonzales LW, Wang ZM, Metcalfe D, Hyde DM, et al. Chronic lung disease in preterm lambs: effect of daily vitamin A treatment on alveolarization. $\mathrm{Am}$ J Physiol Lung Cell Mol Physiol. 2010;299(1):L59-72.

18. Null DM, Alvord J, Leavitt W, Wint A, Dahl MJ, Presson AP, et al. High-frequency nasal ventilation for $21 \mathrm{~d}$ maintains gas exchange with lower respiratory pressures and promotes alveolarization in preterm lambs. Pediatr Res. 2014;75(4):507-16.

29. Joss-Moore LA, Hagen-Lillevik SJ, Yost C, Jewell J, Wilkinson RD, Bowen S, et al. Alveolar formation is dysregulated by restricted nutrition but not excess sedation in preterm lambs managed by noninvasive support. Pediatr Res. 2016;80(5):719-28.

20. Chu, J.E.; Xia, Y.; Chin-Yee, B.; Goodale, D.; Croker, A.K.; Allan, A.L. Lung-derived factors mediate breast cancer cell migration via CD44 receptor-ligand interactions in a novel ex vivo system for analysis of organ-specific soluble proteins. Neoplasia 2014, 16, $180-191$.

21. Iosef C, Liu M, Ying L, Rao SP, Concepcion KR, Chan WK, et al. Distinct roles for IkappaB kinases alpha and beta in regulating pulmonary endothelial angiogenic function during late lung development. J Cell Mol Med. 2018;22(9):4410-22.

22. Montagnani M, Chen H, Barr VA, and Quon MJ. Insulin-stimulated activation of eNOS is independent of $\mathrm{Ca} 2+$ but requires phosphorylation by Akt at $\operatorname{Ser}(1179)$. J Biol Chem. 2001;276(32):30392-8. 
23. Rathel TR, Leikert JJ, Vollmar AM, and Dirsch VM. Application of 4,5diaminofluorescein to reliably measure nitric oxide released from endothelial cells in vitro. Biol Proced Online. 2003;5:136-42.

24. Guo M, Du Y, Gokey JJ, Ray S, Bell SM, Adam M, et al. Single cell RNA analysis identifies cellular heterogeneity and adaptive responses of the lung at birth. Nat Commun. 2019;10(1):37.

25. Pierce JW, Schoenleber R, Jesmok G, Best J, Moore SA, Collins T, et al. Novel inhibitors of cytokine-induced IkappaBalpha phosphorylation and endothelial cell adhesion molecule expression show anti-inflammatory effects in vivo. J Biol Chem. 1997;272(34):21096-103.

26. Son HN, Nam JO, Kim S, and Kim IS. Multiple FAS1 domains and the RGD motif of TGFBI act cooperatively to bind alphavbeta3 integrin, leading to anti-angiogenic and antitumor effects. Biochim Biophys Acta. 2013;1833(10):2378-88.

27. Brooks PC, Clark RA, and Cheresh DA. Requirement of vascular integrin alpha v beta 3 for angiogenesis. Science. 1994;264(5158):569-71.

28. Scatena M, Almeida M, Chaisson ML, Fausto N, Nicosia RF, and Giachelli CM. NFkappaB mediates alphavbeta3 integrin-induced endothelial cell survival. J Cell Biol. 1998;141(4):1083-93.

29. Bhullar IS, Li YS, Miao H, Zandi E, Kim M, Shyy JY, et al. Fluid shear stress activation of IkappaB kinase is integrin-dependent. J Biol Chem. 1998;273(46):30544-9.

30. Dunn SM, Coles LS, Lang RK, Gerondakis S, Vadas MA, and Shannon MF. Requirement for nuclear factor (NF)-kappa B p65 and NF-interleukin-6 binding elements in the tumor necrosis factor response region of the granulocyte colony-stimulating factor promoter. Blood. 1994;83(9):2469-79. 
31. Ueda K, Takano H, Hasegawa H, Niitsuma Y, Qin Y, Ohtsuka M, et al. Granulocyte colony stimulating factor directly inhibits myocardial ischemia-reperfusion injury through Aktendothelial NO synthase pathway. Arterioscler Thromb Vasc Biol. 2006;26(6):e108-13.

32. Roberts RJ, Weesner KM, and Bucher JR. Oxygen-induced alterations in lung vascular development in the newborn rat. Pediatr Res. 1983;17(5):368-75.

33. Bhatt AJ, Pryhuber GS, Huyck H, Watkins RH, Metlay LA, and Maniscalco WM. Disrupted pulmonary vasculature and decreased vascular endothelial growth factor, Flt-1, and TIE-2 in human infants dying with bronchopulmonary dysplasia. Am J Respir Crit Care Med. 2001;164(10 Pt 1):1971-80.

34. Billings PC, Whitbeck JC, Adams CS, Abrams WR, Cohen AJ, Engelsberg BN, et al. The transforming growth factor-beta-inducible matrix protein (beta)ig-h3 interacts with fibronectin. J Biol Chem. 2002;277(31):28003-9.

35. Hanssen E, Reinboth B, and Gibson MA. Covalent and non-covalent interactions of betaigh3 with collagen VI. Beta ig-h3 is covalently attached to the amino-terminal region of collagen VI in tissue microfibrils. J Biol Chem. 2003;278(27):24334-41.

36. Kawamoto T, Noshiro M, Shen M, Nakamasu K, Hashimoto K, Kawashima-Ohya Y, et al. Structural and phylogenetic analyses of RGD-CAP/beta ig-h3, a fasciclin-like adhesion protein expressed in chick chondrocytes. Biochim Biophys Acta. 1998;1395(3):288-92.

37. Bae JS, Lee SH, Kim JE, Choi JY, Park RW, Yong Park J, et al. Betaig-h3 supports keratinocyte adhesion, migration, and proliferation through alpha3betal integrin. Biochem Biophys Res Commun. 2002;294(5):940-8. 
38. Kim JE, Jeong HW, Nam JO, Lee BH, Choi JY, Park RW, et al. Identification of motifs in the fasciclin domains of the transforming growth factor-beta-induced matrix protein betaigh3 that interact with the alphavbeta5 integrin. J Biol Chem. 2002;277(48):46159-65.

39. Nam JO, Kim JE, Jeong HW, Lee SJ, Lee BH, Choi JY, et al. Identification of the alphavbeta3 integrin-interacting motif of betaig-h3 and its anti-angiogenic effect. $J$ Biol Chem. 2003;278(28):25902-9.

40. Schwanekamp JA, Lorts A, Sargent MA, York AJ, Grimes KM, Fischesser DM, et al. TGFBI functions similar to periostin but is uniquely dispensable during cardiac injury. PLoS One. 2017;12(7):e0181945.

41. Billings PC, Herrick DJ, Howard PS, Kucich U, Engelsberg BN, and Rosenbloom J. Expression of betaig-h3 by human bronchial smooth muscle cells: localization To the extracellular matrix and nucleus. Am J Respir Cell Mol Biol. 2000;22(3):352-9.

42. Heine UI, Munoz EF, Flanders KC, Roberts AB, and Sporn MB. Colocalization of TGFbeta 1 and collagen I and III, fibronectin and glycosaminoglycans during lung branching morphogenesis. Development. 1990;109(1):29-36.

43. Serra R, Pelton RW, and Moses HL. TGF beta 1 inhibits branching morphogenesis and Nmyc expression in lung bud organ cultures. Development. 1994;120(8):2153-61.

44. Shull MM, Ormsby I, Kier AB, Pawlowski S, Diebold RJ, Yin M, et al. Targeted disruption of the mouse transforming growth factor-beta 1 gene results in multifocal inflammatory disease. Nature. 1992;359(6397):693-9.

45. Kaartinen V, Voncken JW, Shuler C, Warburton D, Bu D, Heisterkamp N, et al. Abnormal lung development and cleft palate in mice lacking TGF-beta 3 indicates defects of epithelial-mesenchymal interaction. Nat Genet. 1995;11(4):415-21. 
46. Chen H, Sun J, Buckley S, Chen C, Warburton D, Wang XF, et al. Abnormal mouse lung alveolarization caused by Smad3 deficiency is a developmental antecedent of centrilobular emphysema. Am J Physiol Lung Cell Mol Physiol. 2005;288(4):L683-91.

47. Kim JE, Kim SJ, Lee BH, Park RW, Kim KS, and Kim IS. Identification of motifs for cell adhesion within the repeated domains of transforming growth factor-beta-induced gene, betaig-h3. J Biol Chem. 2000;275(40):30907-15.

48. Lee BH, Bae JS, Park RW, Kim JE, Park JY, and Kim IS. betaig-h3 triggers signaling pathways mediating adhesion and migration of vascular smooth muscle cells through alphavbeta5 integrin. Exp Mol Med. 2006;38(2):153-61.

49. Leavesley DI, Schwartz MA, Rosenfeld M, and Cheresh DA. Integrin beta 1- and beta 3mediated endothelial cell migration is triggered through distinct signaling mechanisms. $J$ Cell Biol. 1993;121(1):163-70.

50. Brooks PC, Montgomery AM, Rosenfeld M, Reisfeld RA, Hu T, Klier G, et al. Integrin alpha $\mathrm{v}$ beta 3 antagonists promote tumor regression by inducing apoptosis of angiogenic blood vessels. Cell. 1994;79(7):1157-64.

51. Drake CJ, Cheresh DA, and Little CD. An antagonist of integrin alpha v beta 3 prevents maturation of blood vessels during embryonic neovascularization. J Cell Sci. 1995;108 ( Pt 7):2655-61.

52. Malyankar UM, Scatena M, Suchland KL, Yun TJ, Clark EA, and Giachelli CM. Osteoprotegerin is an alpha vbeta 3-induced, NF-kappa B-dependent survival factor for endothelial cells. J Biol Chem. 2000;275(28):20959-62.

53. Demetri GD, and Griffin JD. Granulocyte colony-stimulating factor and its receptor. Blood. 1991;78(11):2791-808. 
54. Bussolino F, Wang JM, Defilippi P, Turrini F, Sanavio F, Edgell CJ, et al. Granulocyteand granulocyte-macrophage-colony stimulating factors induce human endothelial cells to migrate and proliferate. Nature. 1989;337(6206):471-3.

55. Zsebo KM, Yuschenkoff VN, Schiffer S, Chang D, McCall E, Dinarello CA, et al. Vascular endothelial cells and granulopoiesis: interleukin-1 stimulates release of G-CSF and GMCSF. Blood. 1988;71(1):99-103.

56. Kuldo JM, Westra J, Asgeirsdottir SA, Kok RJ, Oosterhuis K, Rots MG, et al. Differential effects of NF-\{kappa\}B and p38 MAPK inhibitors and combinations thereof on TNF$\{$ alpha $\}$ - and IL-1 $\{$ beta $\}$-induced proinflammatory status of endothelial cells in vitro. Am J Physiol Cell Physiol. 2005;289(5):C1229-39.

57. Lee ST, Chu K, Jung KH, Ko SY, Kim EH, Sinn DI, et al. Granulocyte colony-stimulating factor enhances angiogenesis after focal cerebral ischemia. Brain Res. 2005;1058(12):120-8.

58. Genis L, Gonzalo P, Tutor AS, Galvez BG, Martinez-Ruiz A, Zaragoza C, et al. Functional interplay between endothelial nitric oxide synthase and membrane type 1 matrix metalloproteinase in migrating endothelial cells. Blood. 2007;110(8):2916-23.

59. Lee PC, Salyapongse AN, Bragdon GA, Shears LL, 2nd, Watkins SC, Edington HD, et al. Impaired wound healing and angiogenesis in eNOS-deficient mice. Am J Physiol. 1999;277(4):H1600-8.

60. Zhao X, Lu X, and Feng Q. Deficiency in endothelial nitric oxide synthase impairs myocardial angiogenesis. Am J Physiol Heart Circ Physiol. 2002;283(6):H2371-8. 
61. MacRitchie AN, Albertine KH, Sun J, Lei PS, Jensen SC, Freestone AA, et al. Reduced endothelial nitric oxide synthase in lungs of chronically ventilated preterm lambs. $A m J$ Physiol Lung Cell Mol Physiol. 2001;281(4):L1011-20.

62. Bland RD, Albertine KH, Carlton DP, Kullama L, Davis P, Cho SC, et al. Chronic lung injury in preterm lambs: abnormalities of the pulmonary circulation and lung fluid balance. Pediatr Res. 2000;48(1):64-74.

63. Bland RD, Albertine KH, Carlton DP, and MacRitchie AJ. Inhaled nitric oxide effects on lung structure and function in chronically ventilated preterm lambs. Am J Respir Crit Care Med. 2005;172(7):899-906.

64. Albertine KH, Jones GP, Starcher BC, Bohnsack JF, Davis PL, Cho SC, et al. Chronic lung injury in preterm lambs. Disordered respiratory tract development. Am J Respir Crit Care Med. 1999;159(3):945-58.

65. Li J, Yu KH, Oehlert J, Jeliffe-Pawlowski LL, Gould JB, Stevenson DK, et al. Exome Sequencing of Neonatal Blood Spots and the Identification of Genes Implicated in Bronchopulmonary Dysplasia. Am J Respir Crit Care Med. 2015;192(5):589-96.

66. Hamvas A, Feng R, Bi Y, Wang F, Bhattacharya S, Mereness J, et al. Exome sequencing identifies gene variants and networks associated with extreme respiratory outcomes following preterm birth. BMC Genet. 2018;19(1):94. 
A

Adult PEC with

Starvation Media

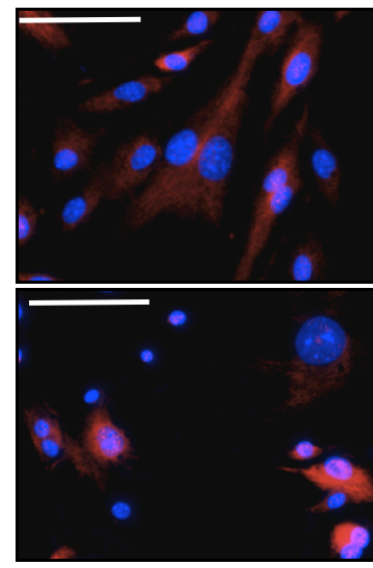

Adult PEC with

Late Alveolar LCM
Adult PEC with

Early Alveolar LCM

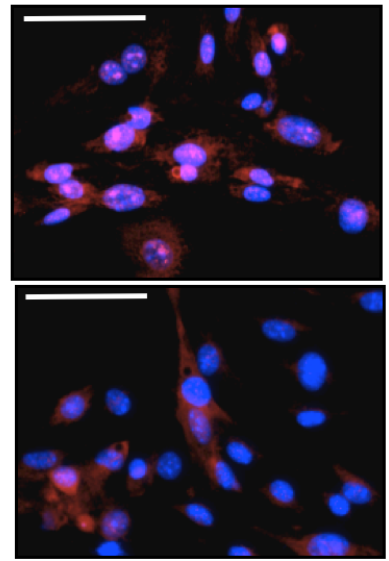

Adult PEC with Adult LCM
B

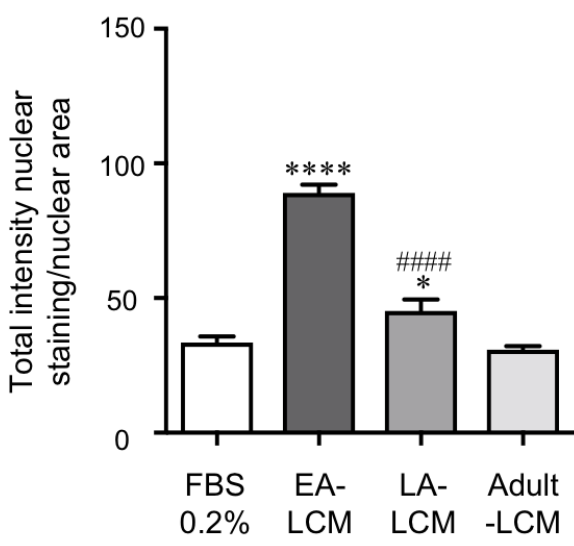

C

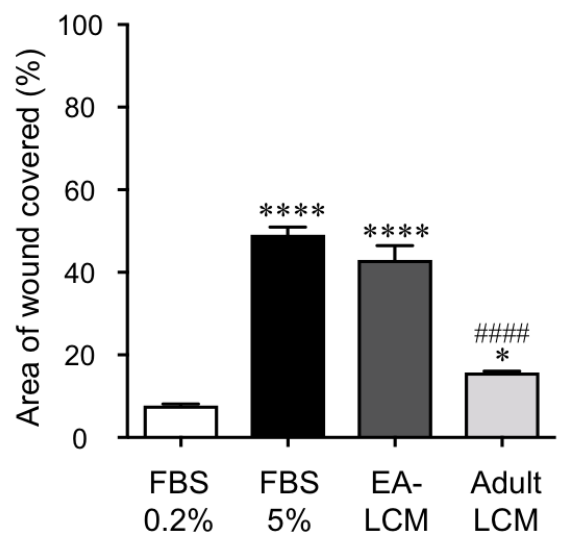

Figure 1 
A
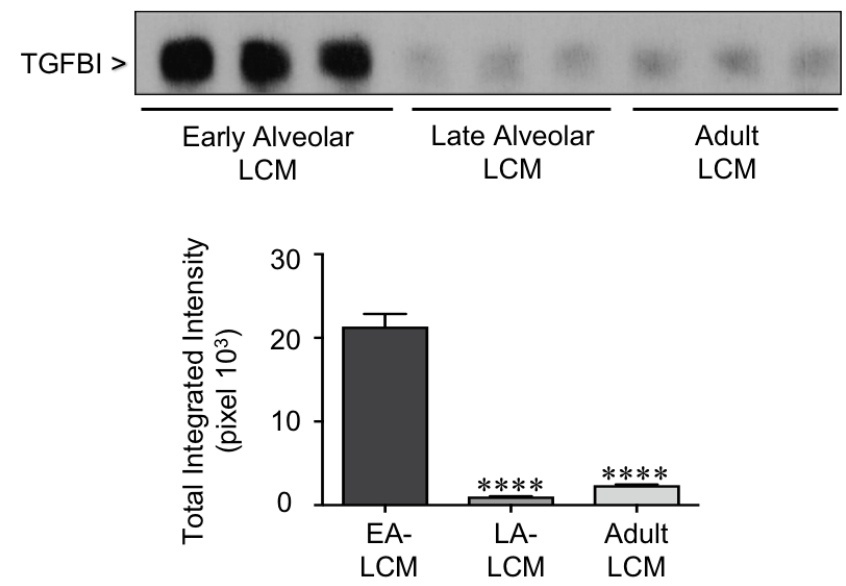

B
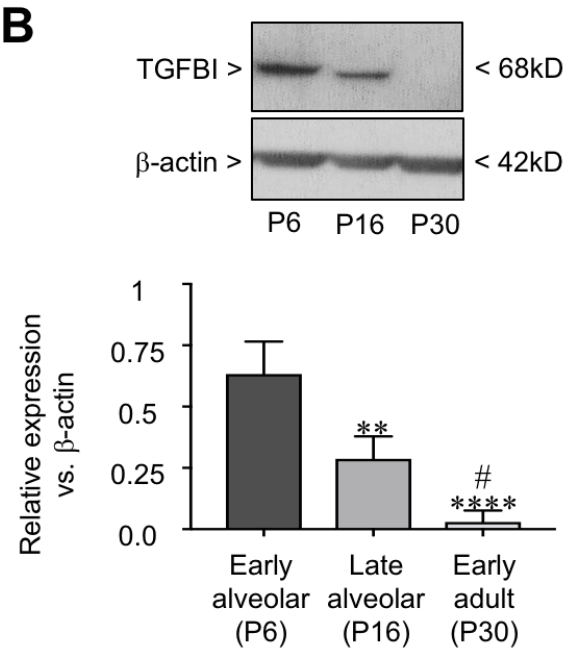

C

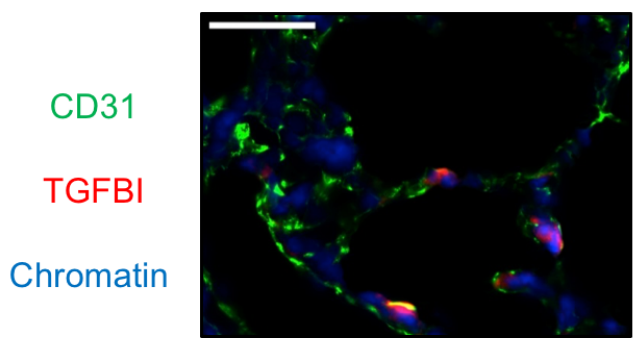

Early Alveolar Lung

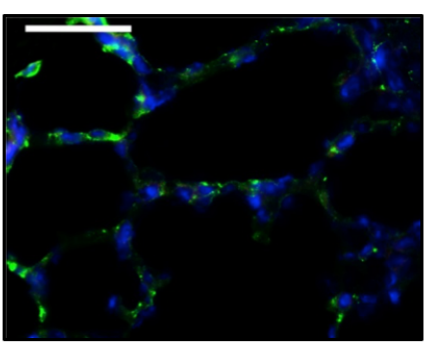

Adult Lung

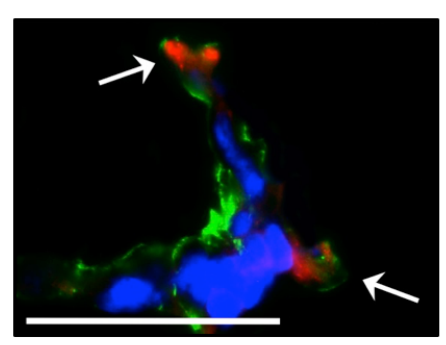

Early Alveolar Lung (High Mag)

D

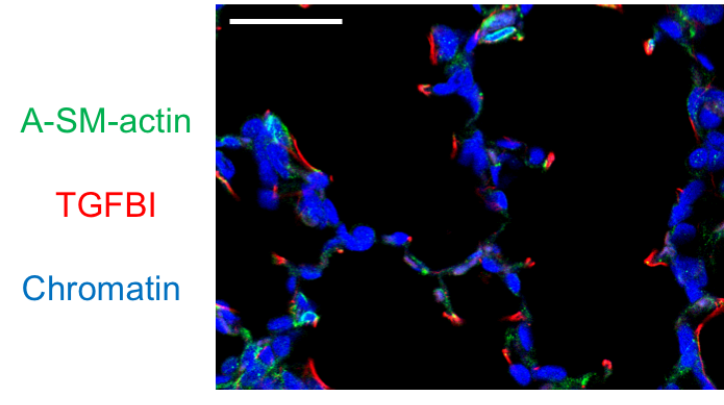

Newborn Lamb 1 day old

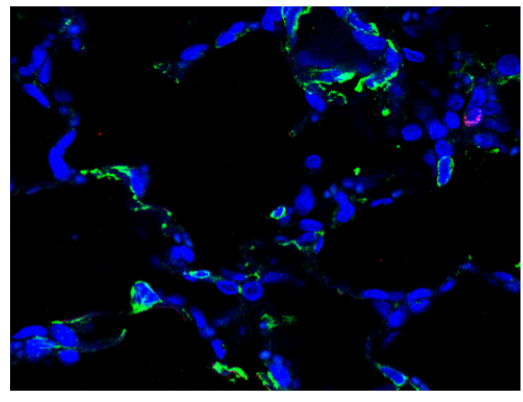

Newborn Lamb 3 weeks old 
A

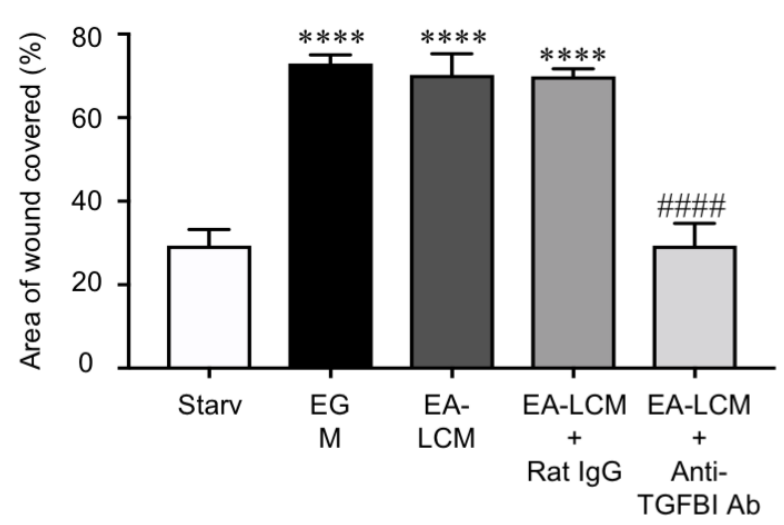

C
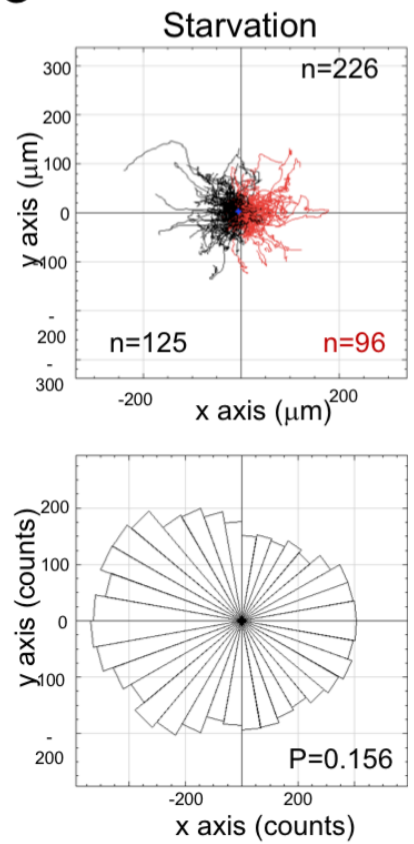

B
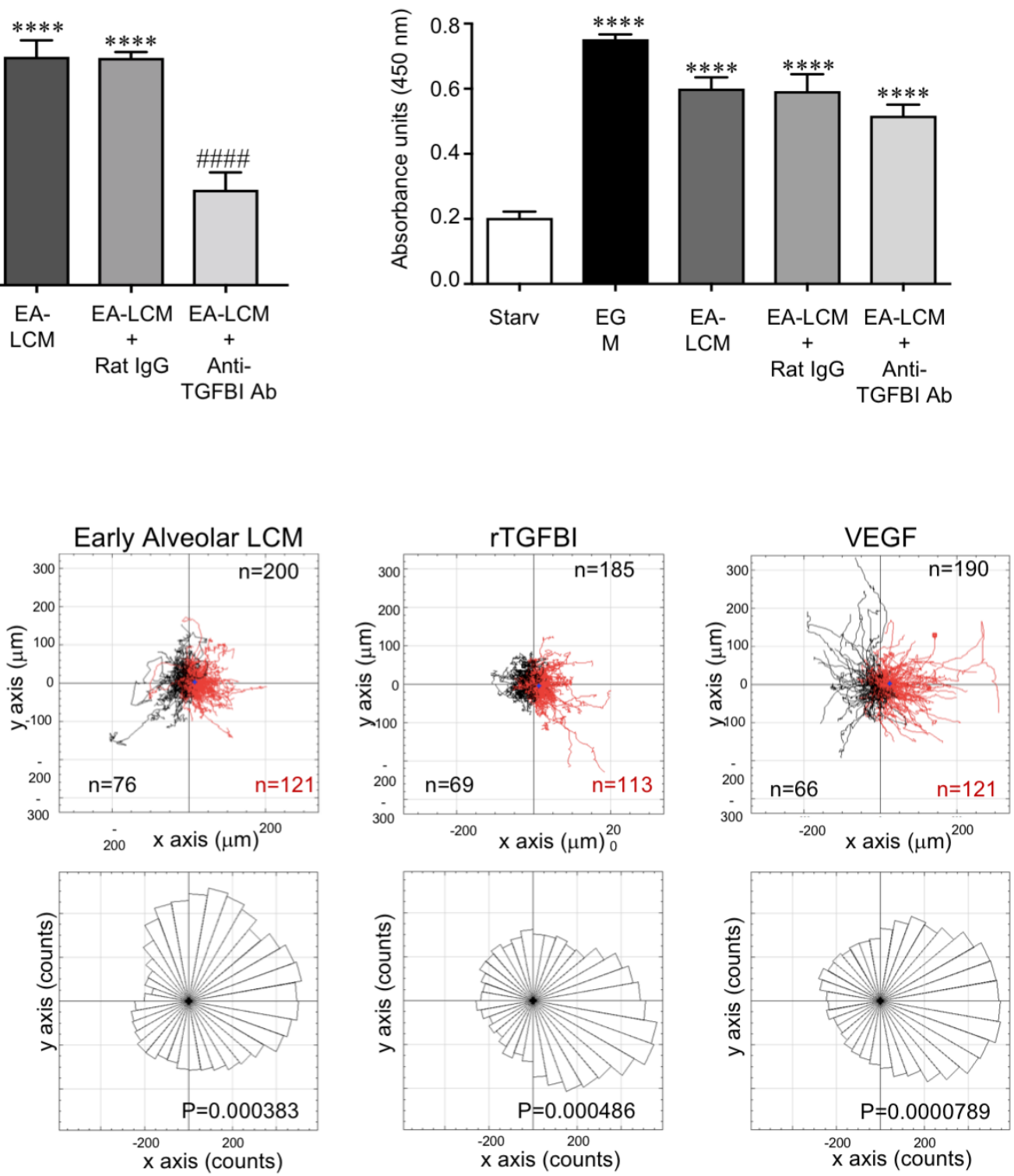

Figure 3 


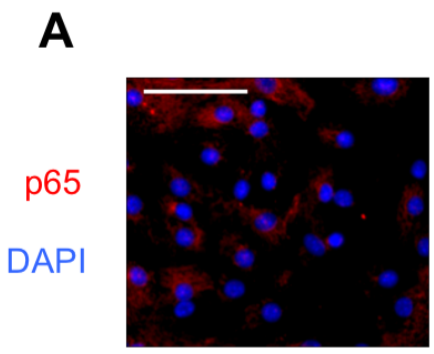

Starv

B

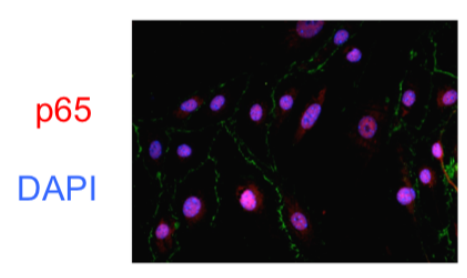

Vehicle



EA-LCM

Rat IgG

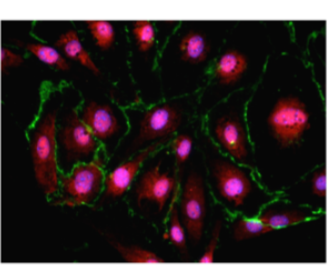

TGFBI

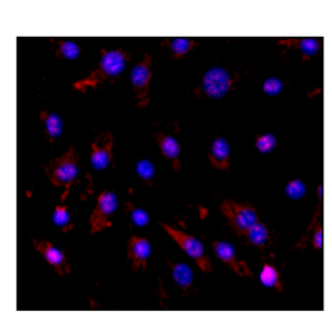

EA-LCM $+$

Anti-TGFBI Ab

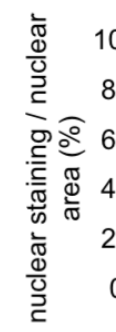

政

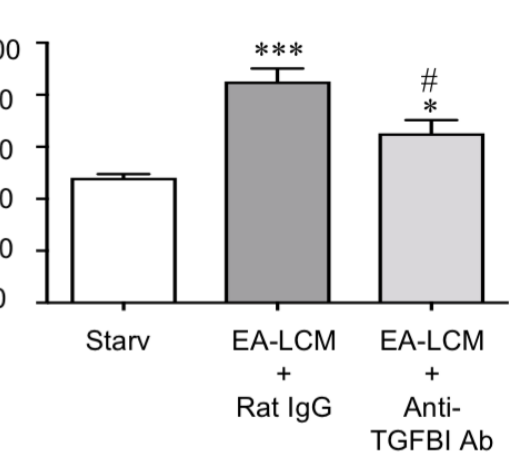

C

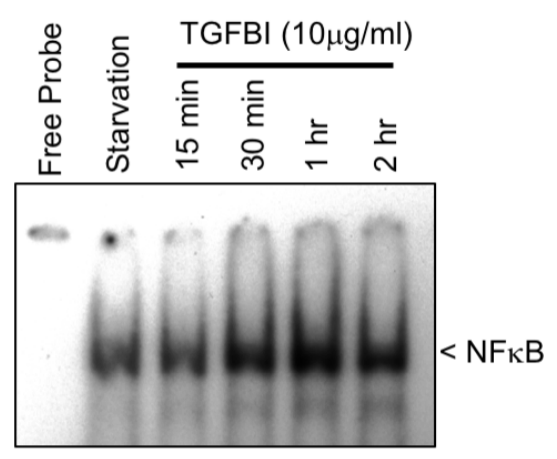

E

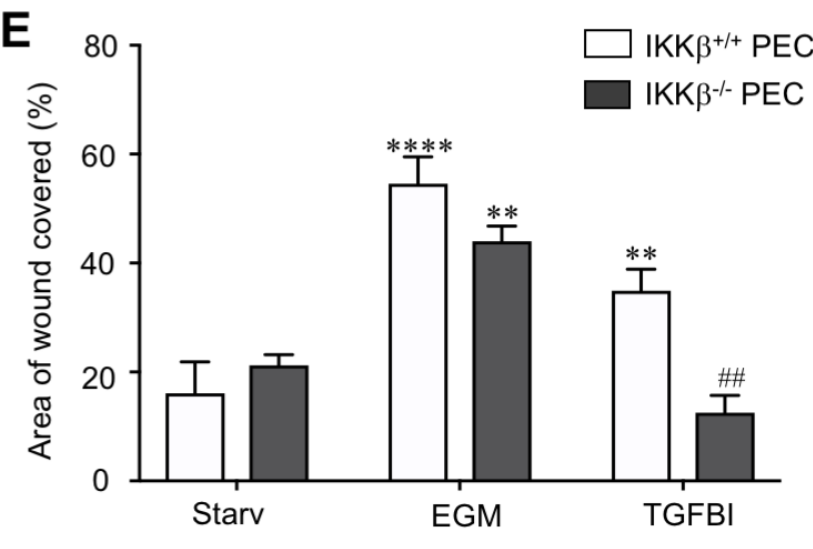

Figure 4 
A

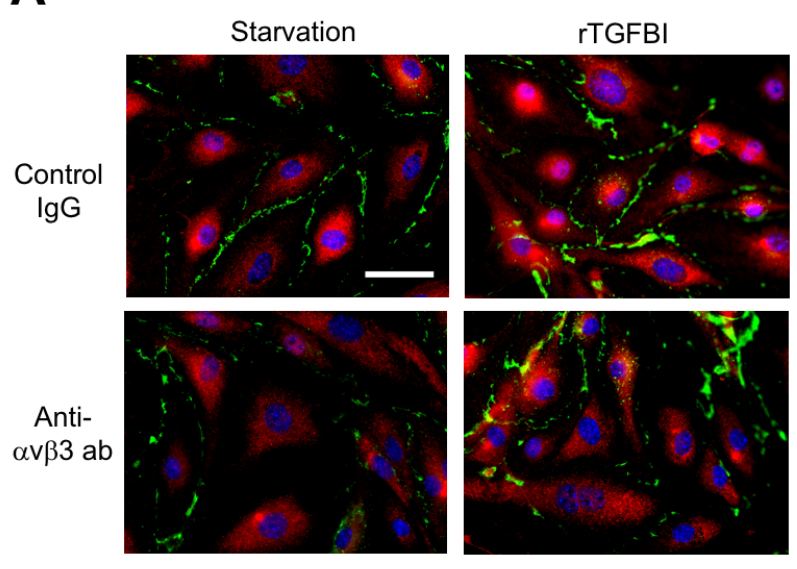

C

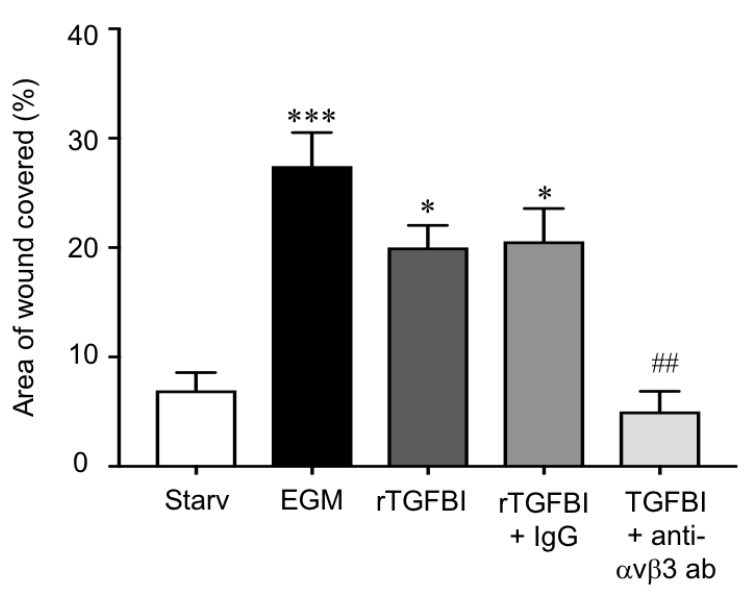

B

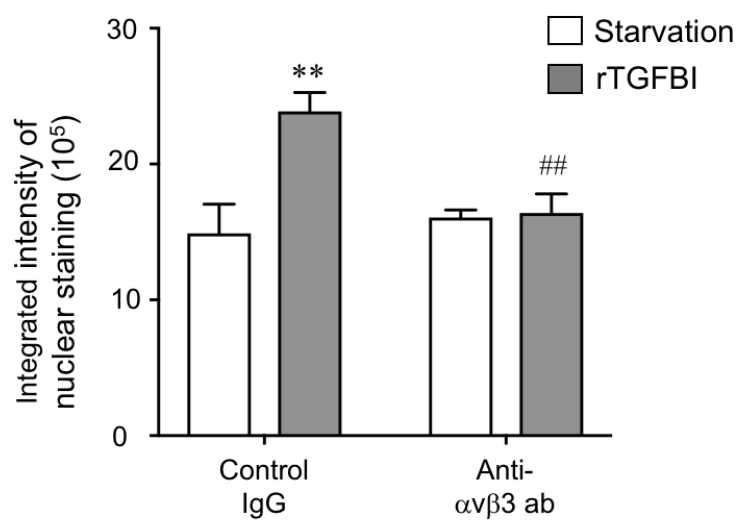

D

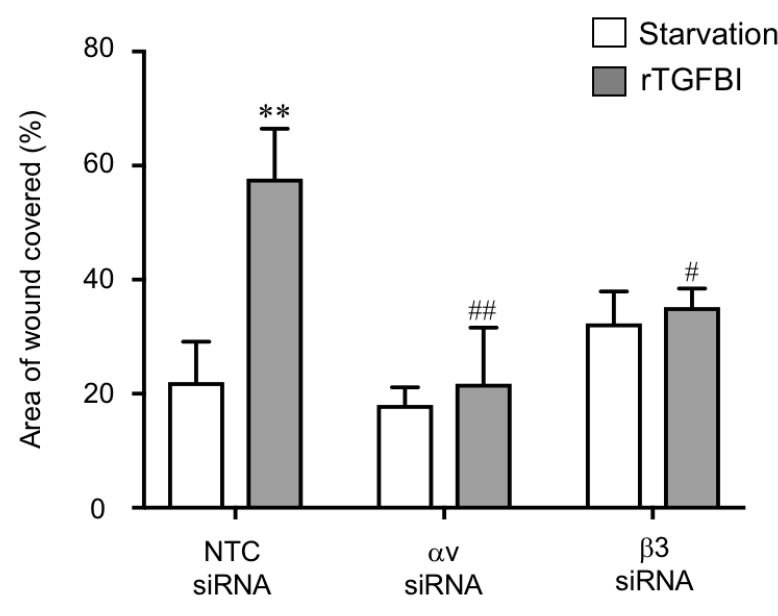

Figure 5 
A

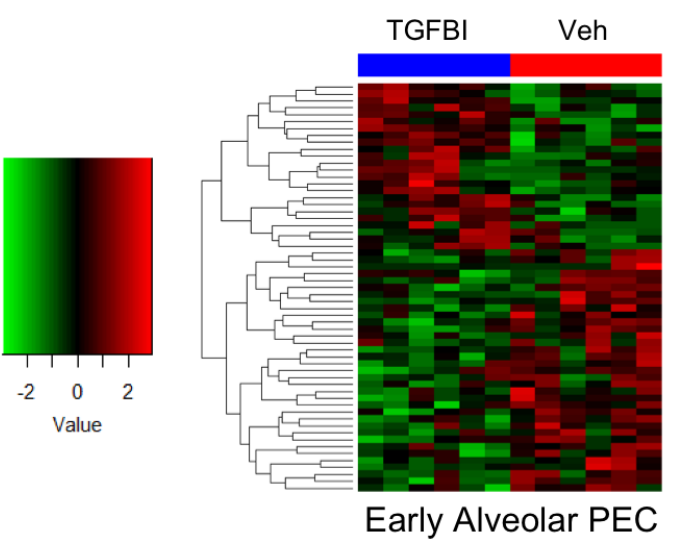

C

\begin{tabular}{|c|c|c|}
\hline \multicolumn{3}{|l|}{ Early Alveolar PEC } \\
\hline $\begin{array}{l}\text { Gene } \\
\text { Name }\end{array}$ & $\begin{array}{l}\text { Fold } \\
\text { Change }\end{array}$ & P value \\
\hline Csf3 & 3.01 & 0.0025 \\
\hline Adult PEC \\
\hline $\begin{array}{c}\text { Gene } \\
\text { Name }\end{array}$ & $\begin{array}{c}\text { Fold } \\
\text { Change }\end{array}$ & P value \\
\hline Csf3 & 2.77 & 0.005 \\
\hline
\end{tabular}

TGFBI Veh B

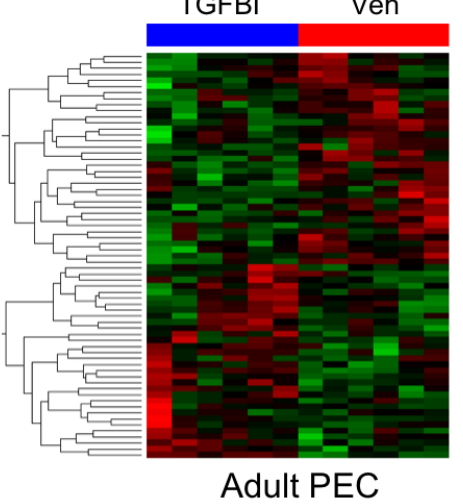

Adult PEC

D



E
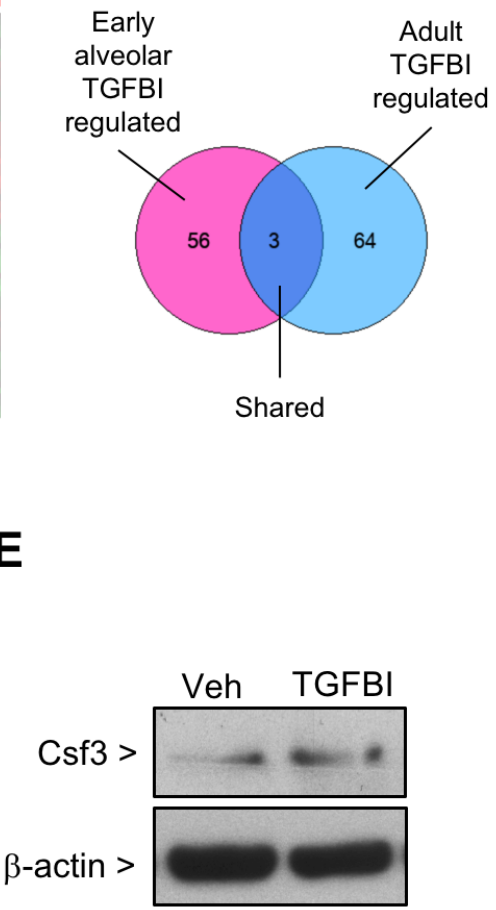

F
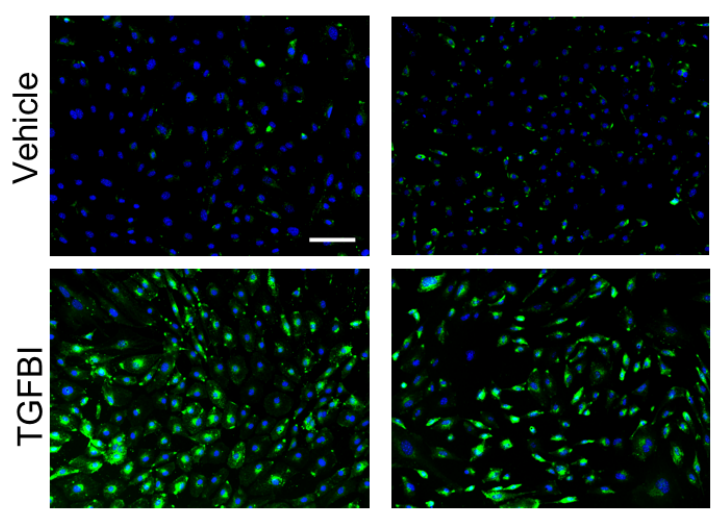

$\square$ Vehicle

$\square$ TGFBI $(10 \mu \mathrm{g} / \mathrm{ml})$
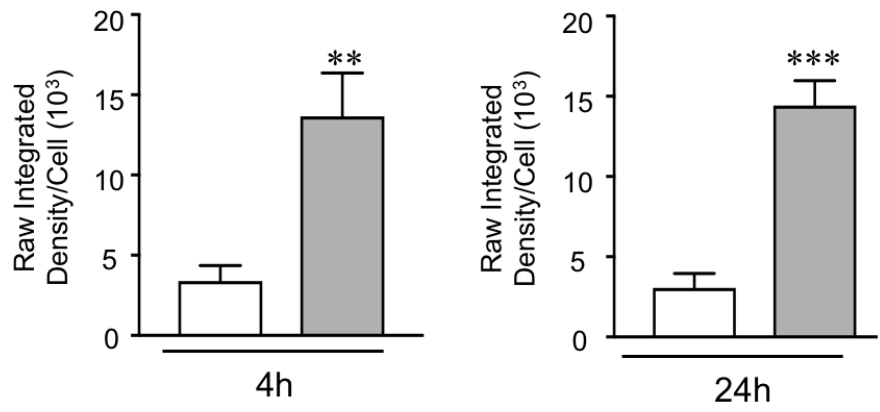

Figure 6 
A
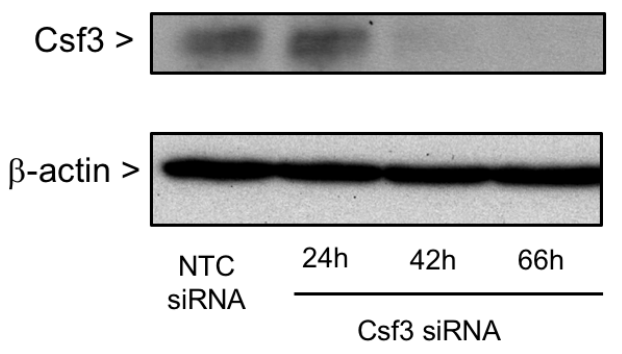

C

C Vehicle

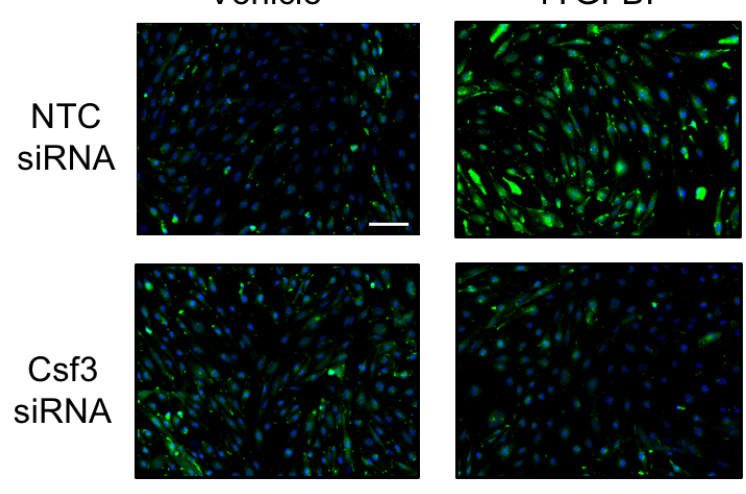

B
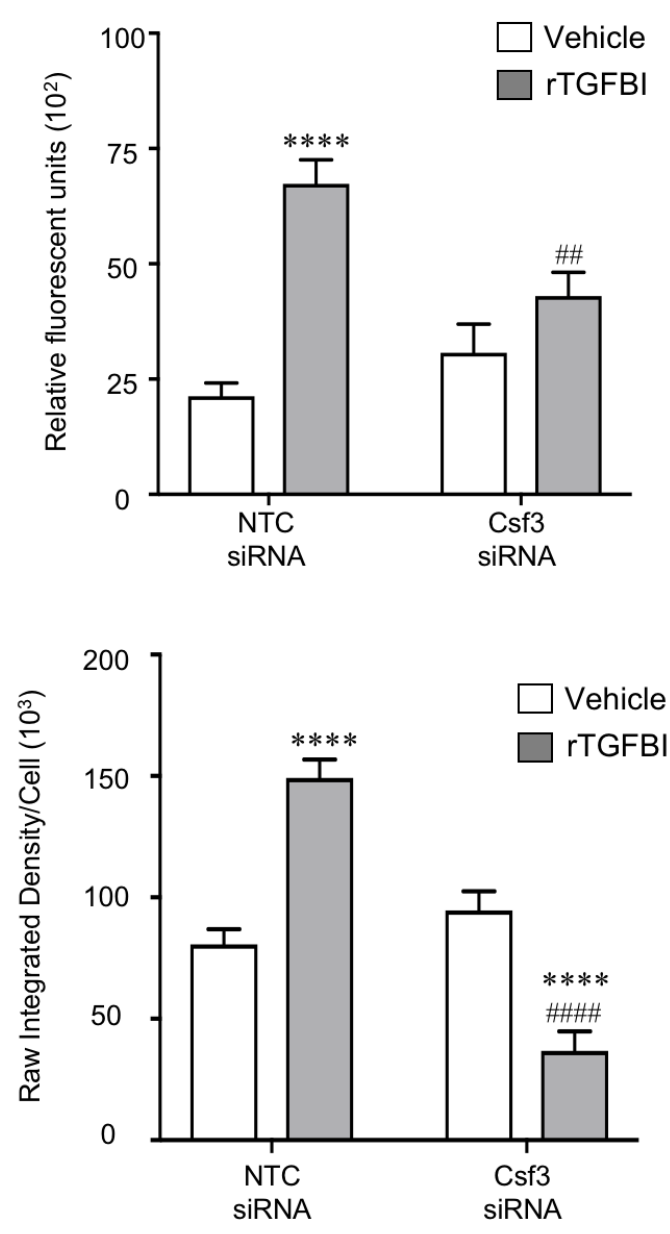

Figure 7 
A

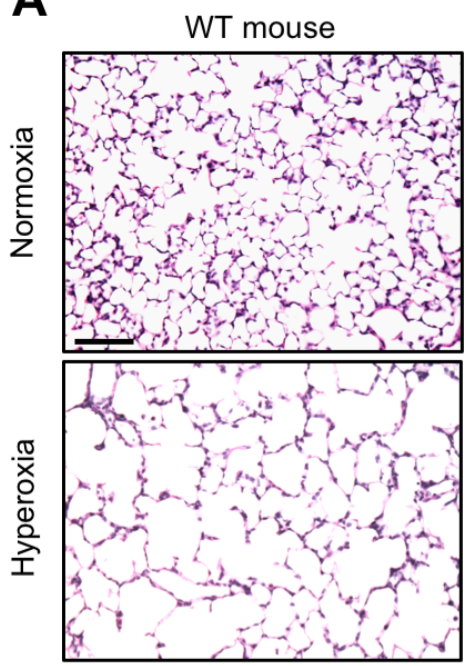

B

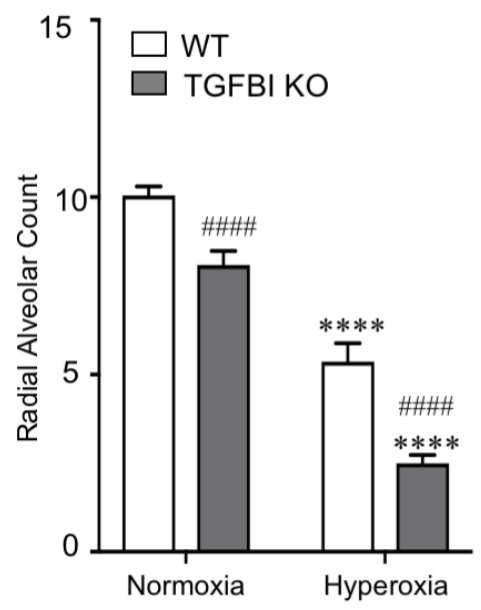

$\mathbf{F}$

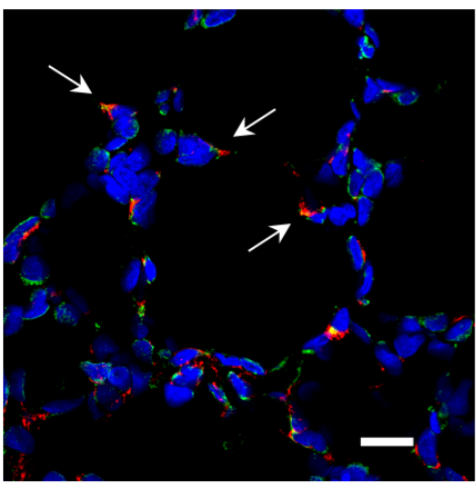

Control Lamb

C
TGFBI(-/-) mouse
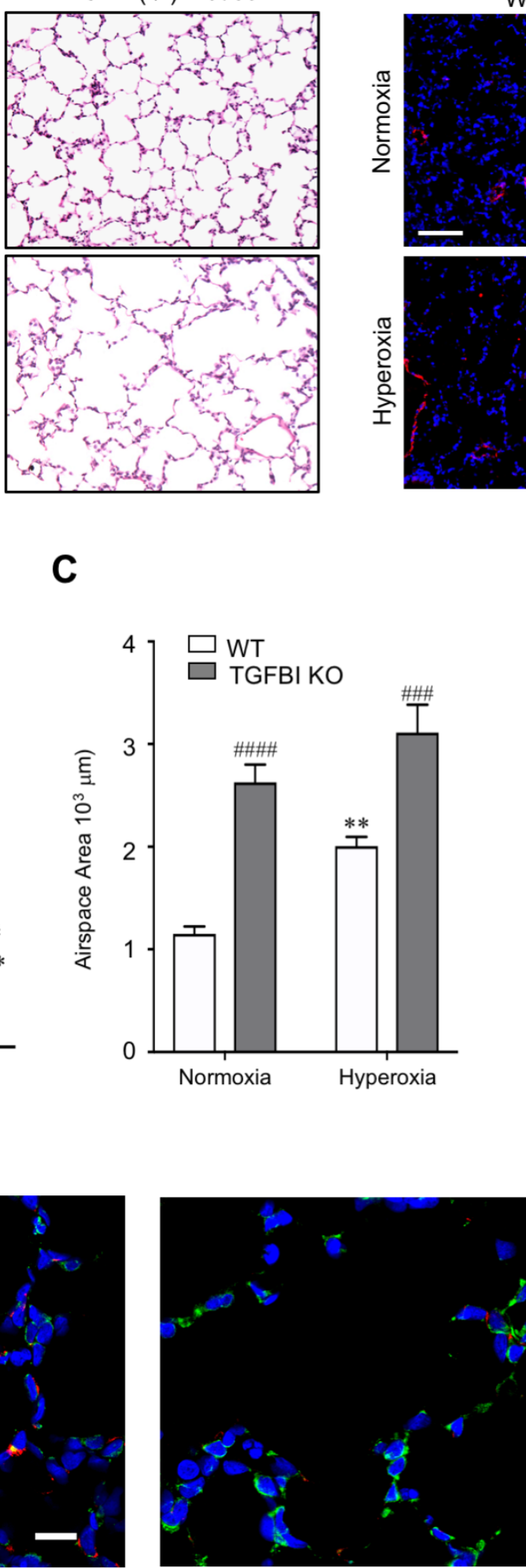

NSR Lamb
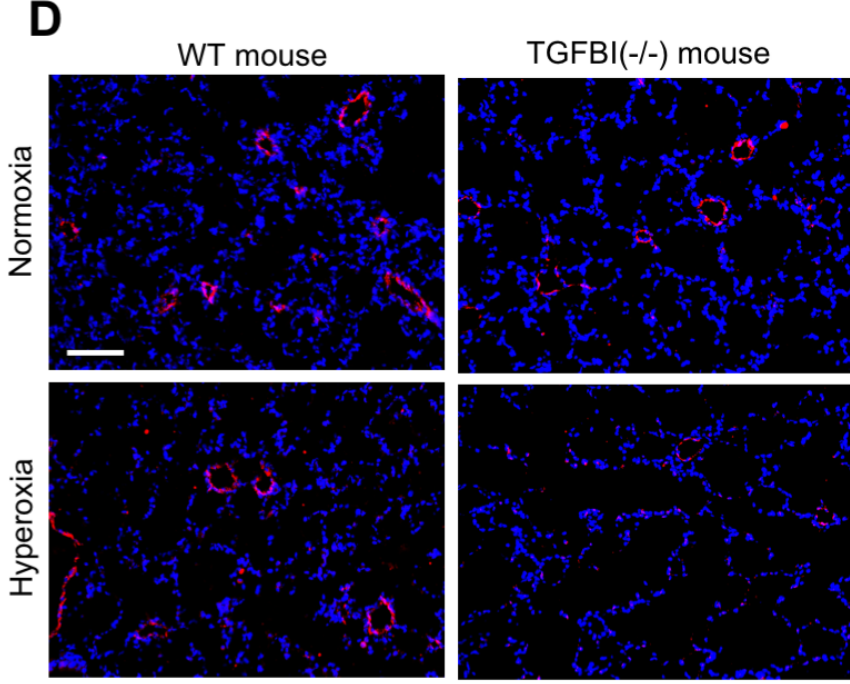

E

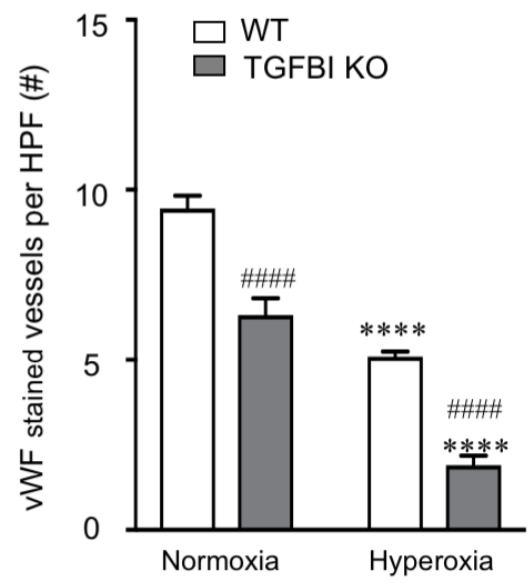

IMV Lamb

Figure 8 